\title{
Omnivorous feeding by planktotrophic larvae of the eastern oyster Crassostrea virginica
}

\author{
Brad S. Baldwin, Roger I. E. Newell \\ Center for Environmental and Estuarine Studies, Horn Point Environmental Laboratory, University of Maryland System, \\ PO Box 775, Cambridge, Maryland 21613, USA
}

\begin{abstract}
In order to better understand the particle diet of planktotrophic larvae of the eastern oyster Crassostrea virginica (Gmelin) we measured their ingestion of naturally occurring food organisms. By using a dual radioisotope ${ }^{3} \mathrm{H}$ and ${ }^{14} \mathrm{C}$ ) labeling technique in conjunction with plankton size fractionation procedures we demonstrate that oyster larvae feed upon bacteria, phagotrophic protozoans and phototrophs present in the diverse summer plankton assemblages of Chesapeake Bay. USA. Prodissoconch II oyster larvae cleared 0.2 to $30 \mu \mathrm{m}{ }^{14} \mathrm{C}$-labeled plankton (primarily phototrophs) at a rate of $0.0825 \mathrm{ml}$ larva $^{-1} \mathrm{~h}^{-1}$, and 0.2 to $30 \mu \mathrm{m}{ }^{3} \mathrm{H}$-labeled plankton (heterotrophic bacteria and phagotrophic protozoans) at a rate of $0.0017 \mathrm{ml} \mathrm{larva}^{-1} \mathrm{~h}^{-1}$ This calculated clearance rate for 0.2 to 30 $\mu \mathrm{m}$ heterotrophs was low due to the predominance of small $(0.2$ to $0.8 \mu \mathrm{m})$, poorly retained bacteria in this size class. Oyster larvae consumed a wide size range of food particles $(0.2-0.8 \mu \mathrm{m}$ to $20-30 \mu \mathrm{m})$ and selectively ingested 20 to $30 \mu \mathrm{m}$ organisms. In other feeding experiments, oyster larvae cleared laboratory cultured heterotrophic flagellates $(12 \mu \mathrm{m})$ at a rate of $0.0640 \mathrm{ml}$ larva $^{-1} \mathrm{~h}^{-1}$ and cultured heterotrophic ciliates $(12 \times 20 \mu \mathrm{m})$ at a rate of $0.1093 \mathrm{ml} \mathrm{larva}^{-1} \mathrm{~h}^{-1}$ The inclusion of heterotrophic food organisms in the diet of $C$. virginica may enhance its growth and development by providing energy and nutrients that supplement those of ingested phytoplankton. We suggest that because oyster larvae ingest non-phytoplankton cells, estimates of standing stocks of phytoplankton may not always be a reliable measure of food supply.
\end{abstract}

\section{INTRODUCTION}

Planktotrophic larvae of benthic marine invertebrates must acquire adequate nutrition from their environment to support their development and metamorphosis to the benthic life stage. For bivalve molluscs, a dominant taxonomic and functional group in many benthic systems, little is known concerning the natural particle diets of their dispersive larvae. Consequently, current understanding of the effects of food availability and nutritional quality on larval growth, survival, and metamorphosis has been derived largely from laboratory studies that have used simplified unialgal diets (for reviews see Bayne 1983, Webb \& Chu 1983, Pechenik 1987, Strathmann 1987). However, in the natural environment, larvae encounter more complex and variable assemblages of food particles. In one of the few studies that examined larval feeding in natural particle assemblages, Fritz et al. (1984) found that planktotrophic larvae of the oyster
Crassostrea virginica (Gmelin) fed upon a variety of phytoplankton taxa present in Delaware Bay, USA. To date, however, no attempt has been made to determine whether bivalve larvae also ingest non-phytoplankton. food organisms (e.g. heterotrophic bacteria, phagotrophic protozoans) that are abundant in coastal systems (e.g. Ducklow \& Kirchman 1983, Davis et al. 1985, Malone et al. 1986, Geider 1988, Stoecker et al. 1989, Dolan \& Coats 1990, Malone \& Ducklow 1990. McManus \& Fuhrman 1990).

Previous studies on the feeding and growth of planktotrophic larvae of bivalves and other taxonomic groups have suggested that non-phytoplankton foods may comprise part of their natural diet. For example, Crisp et al. (1985) considered the standing stocks of 2 to $10 \mu \mathrm{m}$ long phytoflagellates to be insufficient to support the growth of larvae of the bivalve Ostrea edulis. As a supplement to these algae, Crisp et al. (1985) speculated that $O$. edulis larvae feed upon smaller algae, dissolved organic compounds, and 
possibly bacteria and detritus. In studies with echinoderm larvae, Olson (1987) and Olson et al. (1987) measured development and survival of the asteroids Acanthaster planci and Odontaster validus reared in situ in coastal waters of Australia and Antarctica, respectively. In both study sites, standing stocks of phytoplankton were considered to be insufficient to support larval food requirements. However, Olson (1987) found that A. planci developed at near maximal rates and Olson et al. (1987) reported $92.2 \%$ survivorship for $O$. validus. Based on these results, the authors speculated that dissolved organic compounds and nonphytoplankton food particles may have been utilized by these larvae. Utilization of non-phytoplankton foods has been confirmed in other studies. For example, Rivkin et al (1986) found that Antarctic species of echinoderm, polychaete, and nemertean larvae fed extensively on natural populations of bacteria. More recently, Qian \& Chia (1990) reported that 3 species of polychaete larvae grew on detritus collected from seagrass beds and concluded that detritus may play a supplementary role in larval nutrition.

Many holoplanktonic suspension feeders are known to feed as omnivores, even in environments where phytoplankton is abundant. For example several species of copepods ingest attached bacteria detritus, and microzooplankton in addition to phytoplankton (Berk et al. 1977, Landry 1981, Roman 1984a, b, Conley \& Turner 1985, Stoecker \& Sanders 1985, Stoecker \& Egloff 1987, Gifford \& Dagg 1988, Kleppel et al. 1988). Omnivory appears to confer several potential benefits, including: (1) ingestion of more energy and nutrients per unit of feeding effort (Gifford \& Dagg 1988); (2) acquisition of sufficient ration despite a fluctuating balance between autotrophic and heterotrophic food organisms in the natural environment (Landry 1981, Kleppel et al. 1988); and (3) enhanced growth on a mixed diet of plant and detrital (Roman 1984a) or plant and animal foods (Stoecker \& Egloff 1987)

In this study we examine the natural diet of Crassostrea virginica larvae in the mesohaline (ca 7 to 15 ppt) portion of Chesapeake Bay, USA. Specific questions we address are: (1) Do C. virginica larvae feed as omnivores? (2) What is the range of cell sizes ingested by oyster larvae? To answer these questions we used a dual radioisotope labeling technique and plankton size fractionation procedures to differentially label a wide size range of naturally occurring phototrophic and heterotrophic food organisms and to provide a direct measure of particle ingestion by larvae. Our results indicate that $C$. virginica larvae feed as omnivores and that they can capture and ingest food organisms ranging in size between 0.2 to 0.8 and 20 to $30 \mu \mathrm{m}$.

\section{MATERIALS AND METHODS}

Preparation of feeding treatments. We conducted preliminary feeding experiments using fluorescent microspheres (Polysciences, Inc.) to determine the range of particle sizes ingested by larvae of the eastern oyster Crassostrea virginica (Gmelin) and, hence, to establish the size range of natural plankton to offer larvae in feeding experiments (described below). Microspheres of diameter $0.21,0.52,0.94,1.97,3.46$, $4.80,8.2,15.8,21.1$, or $27.4 \mu \mathrm{m}$ were tested in separate feeding trials. Microspheres were suspended in deionized water, sonicated to break apart aggregates, and added to glass vials containing larvae and filtered $(0.2 \mu \mathrm{m})$ autoclave-sterilized estuarine water (SEW) After the feeding trials, larvae were examined using an epifluorescent microscope for the presence of ingested microspheres. In general we could detect ingestion of microspheres $\leq 4.80 \mu \mathrm{m}$ in feeding experiments lasting $\leq 10 \mathrm{~min}$; however, experiments lasting up to $4 \mathrm{~h}$ were necessary for microspheres $\geq 8.2 \mu \mathrm{m}$ because lower microsphere concentrations were used. Negligible reaggregation of microspheres in SEW was detected under our experimental conditions. These experiments demonstrated that larvae up to ca $300 \mu \mathrm{m}$ shell length could ingest microspheres as small as $0.21 \mu \mathrm{m}$. We also found that the maximum particle sizes ingested by larvae ca 150,180, and $300 \mu \mathrm{m}$ in shell length were $15.8,21.1$ and $27.4 \mu \mathrm{m}$, respectively.

Plankton samples from surface $(<1 \mathrm{~m})$ waters of the Choptank River sub-estuary of Chesapeake Bay were collected in $20 \mathrm{l}$ carboys and returned to the laboratory. Based on the particle size ingestion experiments above, we filtered plankton samples through a $30 \mu \mathrm{m}$ Nitex screen using reverse flow gravity filtration in order to provide the most likely size range of larval food organisms and to exclude metazoan grazers. The $<30 \mu \mathrm{m}$ filtrate was placed into several $1 \mathrm{l}$ polycarbonate bottles and dual-labeled (Roman \& Rublee 1981) with filter sterilized $(0.2 \mu \mathrm{m}){ }^{14} \mathrm{C}$-bicarbonate $\left(\mathrm{NaH}^{14} \mathrm{CO}_{3}\right.$, specific activity $=58 \mathrm{mCi}$ mmole ${ }^{-1}, \mathrm{ICN}$ Biomedicals, Inc.) and tritiated-thymidine (methyl$\left[{ }^{3} \mathrm{H}\right]$ - thymidine, specific activity $=60 \mathrm{Cl}$ mole ${ }^{\prime}, \mathrm{ICN}$ Biomedicals, Inc.), each at a final concentration of 0.5 $\mu \mathrm{Ci} \mathrm{ml} l^{-1}$ The final concentration of thymidine was 8.3 nM. Bottles were incubated for $120 \mathrm{~min}$ at $25^{\circ} \mathrm{C}$ over fluorescent light at an intensity of $200 \mu \mathrm{E} \mathrm{m}^{-2} \mathrm{~s}$ ' and were swirled every 10 to $15 \mathrm{~min}$ in order to maintain well-mixed suspensions

Our incubation procedure directly labeled phototrophic organisms (phytoplankton and mixotrophic protozoans) with ${ }^{14} \mathrm{C}$-bicarbonate and heterotrophic bacteria (free-living and attached forms) with ${ }^{3} \mathrm{H}$-thymidine. Studies have shown that eucaryotic microalgae (e.g. Sagan 1965, Swinton \& Hanawalt 1972, 
Pollard \& Moriarty 1984, Rivkin 1986, Rivkin \& Voytek 1986, Martinez et al. 1989) and protozoans (e.g. Plaut \& Sagan 1958, Scherbaum \& Luoderback 1960) can also incorporate ${ }^{3} \mathrm{H}$-thymidine, but these results were derived from experiments that used either unspecified thymidine concentrations and incubation periods, or higher thymidine concentrations (20 to $150 \mathrm{nM}$ ) and/or longer incubation periods (up to $48 \mathrm{~h}$ ) than we employed in the present study. Incorporation of ${ }^{3} \mathrm{H}$ thymidine into cultured cyanobacteria (under similarly high thymidine concentrations) has been documented by Martinez et al. (1989) but not in other studies (Cuhel \& Waterbury 1984, Pollard \& Moriarty 1984).

Significantly, however, in experiments using natural plankton assemblages and low concentrations of added ${ }^{3} \mathrm{H}$-thymidine (5.0 nM), Fuhrman \& Azam (1982) showed that ${ }^{3} \mathrm{H}$-thymidine incorporation is almost completely specific to nonphotosynthetic bacteria. Using microautoradiography, they demonstrated that $<1 \%$ of exposed silver grains were associated with organisms other than bacteria in natural plankton samples that had been labeled for up to $12 \mathrm{~h}$. Similar results have been obtained in a number of other studies that employed microautoradiography to examine ${ }^{3} \mathrm{H}$-thymidine incorporation into natural plankton assemblages (Bern 1985, Fuhrman et al. 1986, Douglas et al. 1987) and sedimentary microorganisms (Carman 1990). Although the likelihood that planktonic organisms will incorporate ${ }^{3} \mathrm{H}$-thymidine is undoubtedly species-, time-, and locationspecific, on the basis of the results from the above autoradiographic studies, we assumed (and later confirmed, see 'Discussion') that under our incubation conditions, negligible amounts of ${ }^{3} \mathrm{H}$-thymidine would be incorporated by organisms other than heterotrophic bacteria

Phagotrophic protozoans can become indirectly labeled with both ${ }^{14} \mathrm{C}$ (via the consumption of ${ }^{14} \mathrm{C}$ labeled phototrophs) and ${ }^{3} \mathrm{H}$ (via the consumption of ${ }^{3} \mathrm{H}$-labeled bacteria). A 120 min prelabeling period was chosen to ensure that plankton food cells were of high specific activity, thereby facilitating detection of ingested cells in short-term (10 min) larval feeding experiments (described below). In addition, on the basis of reported ingestion rates for phagotrophic protozoans (e.g. Lessard \& Swift 1985, McManus \& Fuhrman 1988, Sherr et al. 1988, Sherr et al. 1989) we estimated that an incubation period of $120 \mathrm{~min}$ would be adequate to label phagotrophic protozoans present in the $<30 \mu \mathrm{m}$ filtrate. Based on our labeling procedure, we interpret the ingestion of ${ }^{14} \mathrm{C}$-labeled organisms by larvae to represent consumption of phototrophs and possibly phagotrophic protozoans. On the other hand, we assume that the consumption of particulate forms of ${ }^{3} \mathrm{H}$ by oyster larvae represents ingestion of heterotrophic bacteria and phagotrophic protozoans.

Following the 120 min prelabeling period, the contents of the incubation bottles were pooled and serially size fractioned through filters in order to establish the following feeding treatments: (1) the 0.2 to $30 \mu \mathrm{m}$ size class (no filtration), (2) the 0.2 to $20 \mu \mathrm{m}$ size class, (3) the 0.2 to $10 \mu \mathrm{m}$ size class, (4) the 0.2 to 3 $\mu \mathrm{m}$ size class, and (5) the 0.2 to $0.8 \mu \mathrm{m}$ size class. Plankton was gravity filtered through $20 \mu \mathrm{m}$ Nitex screens and $10 \mu \mathrm{m}$ Nuclepore filters and vacuum filtered ( $\leq 100 \mathrm{~mm} \mathrm{Hg}$ pressure) through $3 \mu \mathrm{m}$ and $0.8 \mu \mathrm{m}$ Nuclepore filters. The lower size limit of all feeding treatments was considered to be $0.2 \mu \mathrm{m}$ given the ability of larvae to ingest particles of this size (see above). Immediately before use in feeding experiments, aliquots were removed from each of the treatments and filtered through $0.2 \mu \mathrm{m}$ Nuclepore filters. Filters were rinsed with SEW and fumed over acetic acid to remove residual ${ }^{14} \mathrm{C}$-bicarbonate as ${ }^{14} \mathrm{CO}_{2}$. Filters were then placed in vials with scintillation cocktail (EcoLite(+), ICN Biomedicals, Inc.) and radioactivity of filtered particles was determined on a Packard Tri-Carb liquid scintillation counter (model 2260XL) which used an external standard and quench correction curve to calculate dpm. Results were expressed as dpm $\mathrm{ml}^{-1}$ of suspension for each of the above size classes. The distribution of particulate label among small and large plankton cells was determined by taking the difference between size class radioactivity. This provided estimates of $\mathrm{dpm} \mathrm{ml}^{-1}$ of suspension in the 0.2 to $0.8 \mu \mathrm{m}, 0.8$ to $3 \mu \mathrm{m}, 3$ to $10 \mu \mathrm{m}$, 10 to $20 \mu \mathrm{m}$, and 20 to $30 \mu \mathrm{m}$ size fractions.

The particle composition of the above feeding treatments was determined using epifluorescent microscopy. Between 2 and $10 \mathrm{ml}$ of each size class were preserved in $1 \%$ gluteraldehyde (final concentration) and stained (if needed) for 4 min. Samples were then filtered onto irgalan black-stained Nuclepore filters and mounted on slides between drops of oil. Heterotrophic (i.e. non-photosynthetic) bacteria and protozoans were viewed under blue light excitation after one of 2 staining treatments: (1) acridine orange staining for enumeration of bacteria (Hobbie et al. 1977), or (2) proflavine staining for enumeration of protozoans (Haas 1982). For both of these organisms, only recognizable and stained cells that did not autofluoresce were counted. Heterotrophs were categorized as bacteria (free-living or attached), flagellates, or ciliates. Autofluorescent phototrophs (no stains used) were examined under blue or green light excitation. Phototrophs were categorized as cyanobacteria, large dinoflagellates (i.e. $>10 \mu \mathrm{m}$ ), or other phototrophs (i.e. all other autofluorescent cells). The 'large dinoflagellate' category was used in order to 
document the abundance of the dinoflagellates Gyrodinium uncatenum and Gymnodinium sanguinium, which were undergoing a population bloom at the time of this experiment. Prepared slides were stored in the dark at $-20^{\circ} \mathrm{C}$ to preserve pigment fluorescence and were viewed within $1 \mathrm{mo}$.

Cell counts were determined for the 0.2 to $0.8 \mu \mathrm{m}$, 0.8 to $3 \mu \mathrm{m}, 3$ to $10 \mu \mathrm{m}$, and 10 to $20 \mu \mathrm{m}$ size fractions by filtering samples from the 0.2 to $0.8 \mu \mathrm{m}, 0.2$ to $3 \mu \mathrm{m}$, 0.2 to $10 \mu \mathrm{m}$, and 0.2 to $20 \mu \mathrm{m}$ size classes through 0.2 , $0.8,3$, and $10 \mu \mathrm{m}$ Nuclepore filters, respectively. Cells counts for the 20 to $30 \mu \mathrm{m}$ size fraction were determined by difference. Here, samples of the 0.2 to $30 \mu \mathrm{m}$ size class were filtered through $10 \mu \mathrm{m}$ filters, cells were counted, and values from the 10 to $20 \mu \mathrm{m}$ fraction were subtracted away, thereby providing counts for the 20 to $30 \mu \mathrm{m}$ fraction.

Test of omnivory. Preceding the radiolabeling procedure mentioned above, prodissoconch II larvae were acclimated to unlabeled $<30 \mu \mathrm{m}$ plankton for $2 \mathrm{~d}$. Larvae were reprovisioned with freshly collected plankton each day. After this acclimation period, and after plankton assemblages were labeled as described above, 10 of these larvae were placed in a bottle ( 3 replicate bottles per treatment) along with $100 \mathrm{ml}$ of a given labeled plankton size class. After a $10 \mathrm{~min}$ grazing period both the larvae and plankton were poured over $95 \mu \mathrm{m}$ Nitex screens in order to separate larvae from labeled plankton. Aliquots of the filtrate

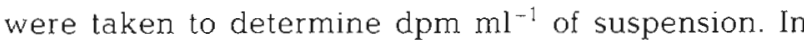
this way we could account for changes in the radioactivity of feeding treatments over the 10 min grazing period (see below). Larvae retained on screens were rinsed with SEW and then fumed over acetic acid to remove residual ${ }^{14} \mathrm{C}$-bicarbonate as ${ }^{14} \mathrm{CO}_{2}$. Larvae were rinsed off the screens and placed into liquid scintillation vials where they were counted and measured on an inverted microscope. The mean shell length of the prodissoconch II larvae was $179 \mu \mathrm{m}$. ( $\pm 5 \mu \mathrm{m}, \mathrm{SD}$ ). Larval tissues were then homogenized via sonication (Branson Sonifier 450) and chemical digestion (Packard Soluene 350). Radioactivity of samples was determined and expressed as dpm larva ${ }^{-1}$. Because feeding treatments contained both radiolabeled particles and dissolved compounds, it was necessary to run simultaneous dissolved uptake experiments using the $\leq 0.2 \mu \mathrm{m}$ filtrate from the labeled plankton suspension. In this way we accounted for adsorption of dissolved label onto larvae as well as absorption by larvae, their associated gut flora, and/or attached cells. Estimates of particle ingestion by larvae were calculated as the difference between total label uptake by larvae in each plankton size class (uptake of particles and dissolved compounds) and uptake of dissolved compounds. Estimates of the particulate label ingested by larvae from each size fraction was calculated by difference. Omnivory was judged as the ability of larvae to ingest both ${ }^{14} \mathrm{C}$-labeled organisms (phototrophs and possibly phagotrophic protozoans) and ${ }^{3} \mathrm{H}$-labeled organisms (heterotrophic bacteria and/or phagotrophic protozoans).

Clearance rates of food organisms. Larval clearance rates of the different sizes and types of planktonic organisms consumed in the above feeding experiments were calculated according to an equation similar to that developed by Daro (1978) and modified by Baars \& Oosterhuis (1984):

$$
\begin{aligned}
& \mathrm{CR}\left(\mathrm{ml} \mathrm{larva}{ }^{-1} \mathrm{~h}^{-1}\right)= \\
& \left(\mathrm{dpm}_{\mathrm{p}}-\mathrm{dpm}_{\mathrm{d}} \text { at time } t\right) \\
& {\left[\left(\begin{array}{cc}
\text { dpm per ml } & \text { dpm per ml } \\
\text { of suspension } & + \text { of suspension } \\
\text { at time } 0 & \text { at time } t
\end{array}\right) 2\right] \times t}
\end{aligned}
$$

where $\mathrm{dpm}_{\mathrm{p}}=\mathrm{dpm}$ larva $\mathrm{a}^{-1}$ held in labeled plankton; $\mathrm{dpm}_{\mathrm{d}}=\mathrm{dpm} \mathrm{larva}^{-1}$ of dissolved controls: $t=$ time of feeding experiment in hours. The denominator of the equation provides an 'average' specific activity for the suspension since planktonic food organisms continue to incorporate label during the $10 \mathrm{~min}$ feeding period. Radioactivity of larvae (dpm larva ${ }^{-1}$ ) was determined as previously described and the radioactivity of the labeled plankton suspension ( $\mathrm{dpm} \mathrm{ml}^{-1}$ ) in each feeding treatment was measured before and after the 10 min feeding period (see above).

Underestimation of $\mathrm{CR}$ due to defecation of consumed label was minimized by using a feeding time of 10 min which is within the 5 to 10 min gut passage time of Crassostrea virginica larvae, as determined in preliminary experiments. Similar experiments also confirmed that these larvae release ingested label in soluble form after feeding periods of $>10 \mathrm{~min}$; therefore, underestimation of $\mathrm{CR}$ due to the loss of consumed label via excretion, respiration or 'leakage (Pechenik 1979) was minimized as well. Overestimation of $C R$ was corrected using previously described experiments controling for uptake of radiolabeled dissolved compounds.

Ingestion of phagotrophic protozoans. We compared larval ingestion of 2 size classes $(0.2$ to $3 \mu \mathrm{m}$ and 0.2 to $30 \mu \mathrm{m}$ ) of organisms prelabeled with ${ }^{3} \mathrm{H}$-thymidine for 2 periods of time (15 and $120 \mathrm{~min}$ ) in order to ascertain larval ingestion of naturally occurring phagotrophic protozoans. Experiments using $120 \mathrm{~min}$ labeled plankton are described above; those using 15 min labeled plankton were conducted in the same fashion. Based on results of the published ${ }^{3} \mathrm{H}$-thymidine labeling studies discussed above, we assumed that during incubations as short as $15 \mathrm{~min}$, negligible amounts of ${ }^{3} \mathrm{H}$ would be taken up by organisms other 
than heterotrophic bacteria. In contrast, we assumed that during 120 min incubations, larger organisms such as phagotrophic protozoans would also become labeled but not eucaryotic algae or cyanobacteria. Also, microscopic examination showed that heterotrophs in the 0.2 to $3 \mu \mathrm{m}$ size class consisted primarily of free-living bacteria although relatively small numbers of attached bacteria and flagellates were also present (Table 1). Larger protozoans and most of the

Table 1. Cell composition of plankton size fractions (cells $\mathrm{ml}^{-1}$ )

\begin{tabular}{|c|c|c|c|c|}
\hline \multicolumn{5}{|c|}{ Phototrophs } \\
\hline $\begin{array}{c}\text { Size fraction } \\
(\mu \mathrm{m})\end{array}$ & \multicolumn{2}{|c|}{$\begin{array}{c}\text { Cyanobacteria } \\
\left(\times 10^{3}\right)\end{array}$} & $\begin{array}{c}\text { Large } \\
\text { dinoflagellates }\end{array}$ & $\begin{array}{l}\text { Others } \\
\left(\times 10^{3}\right)\end{array}$ \\
\hline $0.2-0.8$ & \multicolumn{2}{|c|}{2.13} & & \\
\hline $0.8-3$ & \multicolumn{2}{|c|}{143.15} & & 1.71 \\
\hline $3-10$ & \multicolumn{2}{|c|}{23.70} & & 9.38 \\
\hline $10-20$ & \multirow{2}{*}{\multicolumn{2}{|c|}{3.19}} & 27 & 0.69 \\
\hline $20-30$ & & & 819 & 0.56 \\
\hline \multicolumn{5}{|c|}{ Heterotrophs } \\
\hline $\begin{array}{c}\text { Size } \\
\text { fraction } \\
(\mu \mathrm{m})\end{array}$ & $\begin{array}{c}\text { Free } \\
\text { bacteria } \\
\left(\times 10^{3}\right)\end{array}$ & $\begin{array}{c}\text { Attached } \\
\text { bacteria } \\
\left(\times 10^{3}\right)\end{array}$ & $\begin{array}{l}\text { Flagellates } \\
\qquad\left(\times 10^{3}\right)\end{array}$ & Ciliates \\
\hline $0.2-0.8$ & 5710.60 & & & \\
\hline $0.8-3$ & 518.21 & 0.76 & 0.25 & \\
\hline $3-10$ & 0.24 & 3.73 & 4.48 & \\
\hline $10-20$ & 0.18 & 4.01 & 0.09 & 7 \\
\hline $20-30$ & 0.12 & 1.86 & 0.02 & 4 \\
\hline
\end{tabular}

attached bacteria were present in the 3 to $30 \mu \mathrm{m}$ size fraction. This experimental design therefore compared the following food treatments: (1) the 0.2 to $3 \mu \mathrm{m}$ size class incubated for $15 \mathrm{~min}$, comprised of labeled freeliving bacteria, small numbers of labeled attached bacteria, and small unlabeled flagellates; (2) the 0.2 to $30 \mu \mathrm{m}$ class at $15 \mathrm{~min}$, comprised of labeled free and attached bacteria and unlabeled protozoans; (3) the 0.2 to $3 \mu \mathrm{m}$ class at $120 \mathrm{~min}$, comprised of labeled bacteria and labeled flagellates; and (4) 0.2 to $30 \mu \mathrm{m}$ class at 120 min, comprised of labeled free and attached bacteria and labeled protozoans.

We also tested the ability of larvae to capture and ingest laboratory cultured heterotrophic flagellates and ciliates. An axenic culture of the heterotrophic flagellate Isonema papillatum ( 8 to $12 \mu \mathrm{m}$ maximum length) was incubated with ${ }^{14} \mathrm{C}$-glucose $\left({ }^{14} \mathrm{C}\right.$-D glucose, specific activity $=6.12 \mathrm{mCi} \mathrm{mmol}{ }^{-1}$, ICN Biomedicals, Inc.) at a final concentration of $0.5 \mu \mathrm{Ci}$ $\mathrm{ml}^{-1}$ for $12 \mathrm{~h}$. The labeled culture was then centrifuged for $10 \mathrm{~min}$ at $30 \times \mathrm{g}$, the supernatant containing residual dissolved label was removed, and the culture was resuspended in SEW. Aliquots of the labeled, washed culture were added to $20 \mathrm{ml}$ vials along with SEW to achieve a final cell density of $2.5 \times 10^{4} I$. pap- illatum $\mathrm{ml}^{-1}$. Crassostrea virginica larvae (mean shell length $\pm \mathrm{SD} ; 237 \pm 13 \mu \mathrm{m})$ were acclimated to unlabeled $I$. papillatum $\left(2 \times 10^{4} \mathrm{I}\right.$. papillatum $\left.\mathrm{m} \mathrm{l}^{-1}\right)$ for $12 \mathrm{~h}$ and then added to the experimental vials at a final density of 1 larva $\mathrm{ml}^{-1}$. Larvae were allowed to feed on labeled $I$. papillatum for up to $60 \mathrm{~min}$. At 5, 15, 30, and $60 \mathrm{~min}, 5$ replicate vials were filtered through $95 \mu \mathrm{m}$ Nitex screens and the larvae were processed as described above. Dissolved control experiments were run using the same volume of $\leq 0.2 \mu \mathrm{m}$ filtrate from the labeled I. papillatum culture. Ingestion of ${ }^{14} \mathrm{C}$-labeled I. papillatum was calculated as larval uptake of ${ }^{14} \mathrm{C}$ in vials containing labeled $I$. papillatum and residual dissolved ${ }^{14} \mathrm{C}$ compounds minus larval uptake of ${ }^{14} \mathrm{C}$ in vials containing residual dissolved ${ }^{14} \mathrm{C}$ compounds. Larval ingestion rate (IR, cells larva ${ }^{-1} \mathrm{~h}^{-1}$ ) was calculated according to the least-squares regression equation fitted to the uptake of ${ }^{14} \mathrm{C}$-labeled I. papillatum by larvae. Larval clearance rate (CR, ml larva ${ }^{-1} \mathrm{~h}^{-1}$ ) was calculated as: $\mathrm{CR}=\mathrm{IR} / I$. papillatum $\mathrm{ml}^{-1}$

Another timecourse ingestion experiment was conducted using a bacterized culture of a $12 \times 20 \mu \mathrm{m}$ heterotrich ciliate (clone Smcil, isolated from Chesapeake Bay by $E$. Lessard and tentatively identified as either Diplogmus sp. or Propygocirrus sp.). Smcil was incubated with ${ }^{3} \mathrm{H}$-thymidine (final concentration 0.5 $\mu \mathrm{Ci} \mathrm{ml} \mathrm{m}^{-1}$ ) for $12 \mathrm{~h}$. In this way, the ciliates became labeled with ${ }^{3} \mathrm{H}$ via phagocytosis of ${ }^{3} \mathrm{H}$-labeled bacteria. An aliquot of this culture was placed in a filter tower over a $5 \mu \mathrm{m}$ Nuclepore filter with no vacuum applied. The suspension was rinsed 5 times with an equal volume of SEW in order to retain ${ }^{3} \mathrm{H}$-labeled ciliates while allowing passage of dissolved label and labeled bacteria. The $>5 \mu \mathrm{m}$ suspension was then removed and centrifuged for $10 \mathrm{~min}$ at $30 \times \mathrm{g}$ and the supernatant, which contained residual dissolved label, bacteria, and some ciliates, was removed. Remaining ciliates were then resuspended in SEW and the centrifuge washing procedure repeated. Microscopic observation confirmed that nearly all of the remaining ciliates were alive and swimming. The resulting ciliate suspension was separated into whole water ( ${ }^{3} \mathrm{H}$-labeled ciliates, residual bacteria, and residual dissolved label) and $<5 \mu \mathrm{m}$ (residual bacteria and residual dissolved label) size fractions. Sufficient volume of the whole water fraction was then added to 3 sets of triplicate $100 \mathrm{ml}$ bottles each containing 10 larvae (mean shell length $\pm \mathrm{SD} ; 273 \pm 17 \mu \mathrm{m}$ ) and $<30 \mu \mathrm{m}$ unlabeled plankton such that a final density of 17 labeled ciliates $\mathrm{ml}^{-1}$ was achieved. The same volume of the $<5 \mu \mathrm{m}$ fraction was added to a separate set of bottles containing larvae. Larvae were allowed to feed on these mixtures for up to $360 \mathrm{~min}$. At 30,120 , and $360 \mathrm{~min}$ a set of 3 replicate bottles was filtered onto $95 \mu \mathrm{m}$ Nitex screens and larvae processed as described above. Ingestion of 
${ }^{3} \mathrm{H}$-labeled ciliates was calculated as larval uptake of ${ }^{3} \mathrm{H}$ in whole water minus larval uptake of ${ }^{3} \mathrm{H}$ in the $<5$ $\mu \mathrm{m}$ treatments. Larval ingestion and clearance rates were calculated as for Isonema papillatum.

Statistical analysis. Statistical differences among treatments were tested using 1-way ANOVA. Data were log-transformed to satisfy the assumptions of ANOVA. Where significant differences were indicated, log-transformed treatment means were then compared using the Student-Newman-Keuls (SNK) multiple range test. For data presentation, means have been back-transformed to the linear scale and $95 \%$ confidence intervals calculated as estimates of reliability (Sokal \& Rohlf 1981). All statistical analyses were conducted using SAS software.

\section{RESULTS}

\section{Types and sizes of ingested food organisms}

Crassostrea virginica larvae ingested ${ }^{14} \mathrm{C}$ - and ${ }^{3} \mathrm{H}$ labeled organisms and took up dissolved radiolabeled compounds. Total label uptake (i.e. dissolved uptake plus ingestion of labeled particles) was significantly $(p<0.05)$ greater than dissolved uptake in all feeding treatments, thereby confirming that labeled cells were ingested. Uptake of dissolved radioactive compounds by larvae and/or their associated gut or epibiotic flora accounted for as little as $0.2 \%$ and $5.3 \%$ of total ${ }^{14} \mathrm{C}$ and ${ }^{3} \mathrm{H}$ uptake, respectively, by larvae in the 0.2 to 30 um feeding treatment. However, due to the presence of less particulate label (Figs, $1 \mathrm{~b} \& 2 \mathrm{~b}$ ), dissolved uptake was as high as 31 and $26 \%$ of total ${ }^{14} \mathrm{C}$ and ${ }^{3} \mathrm{H}$ uptake, respectively, in the 0.2 to $0.8 \mu \mathrm{m}$ treatment.

Larval ingestion of ${ }^{14} \mathrm{C}$ and ${ }^{3} \mathrm{H}$-labeled organisms (i.e. total label uptake minus dissolved label uptake) is illustrated in Figs. 1 \& 2. Larger plankton size classes contained significantly $(p<0.05)$ greater amounts of particulate ${ }^{14} \mathrm{C}$ per ml (Fig. 1 b) and as a result, larvae generally ingested significantly $(p<0.05)$ more particulate ${ }^{14} \mathrm{C}$ when fed larger classes of labeled plankton (Fig. 1a). An exception was the similar amount of ingested particulate ${ }^{14} \mathrm{C}$ from the 0.2 to $3 \mu \mathrm{m}$ and 0.2 to $10 \mu \mathrm{m}$ feeding treatments, which suggests that insignificant amounts of 3 to $10 \mu \mathrm{m}{ }^{14} \mathrm{C}$-labeled cells were ingested. The vast majority (ca $87 \%$ ) of ingested ${ }^{14} \mathrm{C}$ carbon came from 20 to $30 \mu \mathrm{m}$ cells (Fig. 1a). This cell size fraction contained a similar amount $(22 \%)$ of the total particulate ${ }^{14} \mathrm{C}$ as the 10 to $20 \mu \mathrm{m}(25 \%), 3$ to 10 $\mu \mathrm{m}(22 \%)$, and 0.8 to $3 \mu \mathrm{m}(20 \%)$ fractions (Fig. $3 a$ ). Cyanobacteria were the only phototrophs detected in the 0.2 to $0.8 \mu \mathrm{m}$ size class (Table 1). Phototrophs in the 0.2 to $3 \mu \mathrm{m}$ class included flagellates, diatoms and coccoid forms (listed together as 'others' in Table 1) but overall the class was dominated by cyanobacteria. The overall composition of larger size classes was similar although large numbers of dinoflagellates (primarily 20 to $30 \mu \mathrm{m}$ in size), which were undergoing a population bloom at the time of this experiment, were present in the 0.2 to $30 \mu \mathrm{m}$ size class.

In contrast to ${ }^{14} \mathrm{C}$ data, larvae ingested statistically similar amounts of particulate ${ }^{3} \mathrm{H}$ from the 0.2 to $0.8 \mu \mathrm{m}$, 0.2 to $3 \mu \mathrm{m}, 0.2$ to $10 \mu \mathrm{m}$, and 0.2 to $20 \mu \mathrm{m}$ size classes (Fig. 2a). The 0.2 to $3 \mu \mathrm{m}$ and larger size classes contained significantly $(\mathrm{p}<0.05)$ more particulate ${ }^{3} \mathrm{H}$ than the 0.2 to $0.8 \mu \mathrm{m}$ class but were not statistically different from each other (Fig 2b). It is apparent from these results that larvae ingested insignificant quantities of ${ }^{3} \mathrm{H}$-labeled 0.8 to $3 \mu \mathrm{m}$ cells. The amount of particulate ${ }^{3} \mathrm{H}$ that larvae ingested in the 0.2 to $30 \mu \mathrm{m}$ size class was not statistically different from that
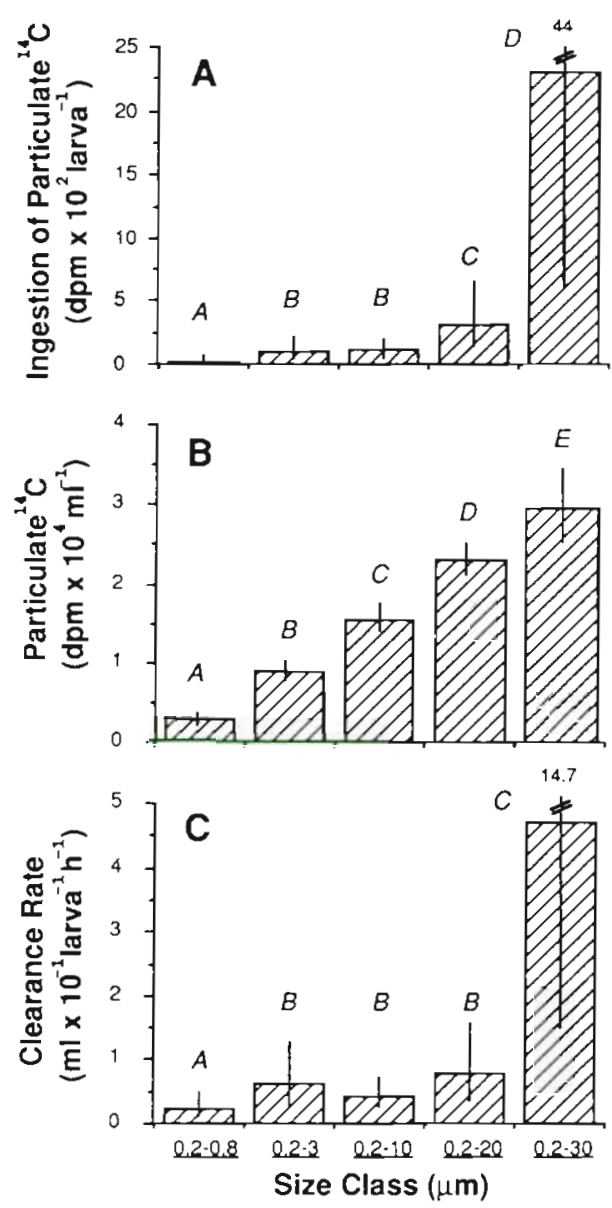

Fig. 1. Crassostrea virginica. Larval ingestion and clearance of various size classes of ${ }^{14} \mathrm{C}$-labeled plankton. $(\mathrm{A}) \mathrm{dpm}$ of ${ }^{14} \mathrm{C}$ ingested per larva $(\mathrm{B}) \mathrm{dpm}$ of ${ }^{14} \mathrm{C}$ per $\mathrm{ml}$ of planktoni $(\mathrm{C})$ clearance rates for plankton size classes. Columns represent means $(n=3)$, error bars are $95 \%$ confidence intervals Columns and error bars have been back-transformed from $\log$-transformed data. Columns with the same letter are not significantly different (SNK multiple range test, $p<0.05$ ) 

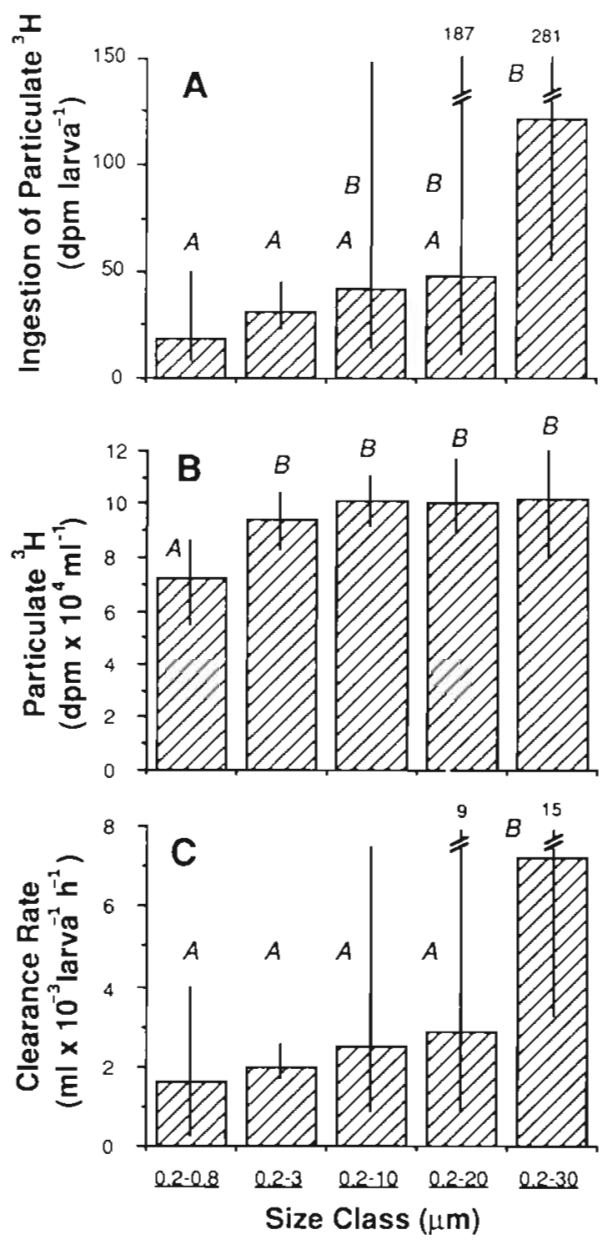

Fig. 2. Crassostrea virginica. Larval ingestion and clearance of various size classes of ${ }^{3} \mathrm{H}$-labeled plankton. (A) dpm of ${ }^{3} \mathrm{H}$ ingested per larva; $(\mathrm{B}) \mathrm{dpm}$ of ${ }^{3} \mathrm{H}$ per $\mathrm{ml}$ of plankton; (C) clearance rates for plankton size classes. Other details as in Fig. 1

ingested in the 0.2 to $10 \mu \mathrm{m}$ or 0.2 to $20 \mu \mathrm{m}$ classes but it was significantly $(p<0.05)$ greater than that ingested in the 0.2 to $0.8 \mu \mathrm{m}$ or 0.2 to $3 \mu \mathrm{m}$ classes (Fig. 2a). This indicates that larvae ingested 3 to $30 \mu \mathrm{m}$ heterotrophs. Cells 3 to $30 \mu \mathrm{m}$ contained only $8 \%$ of the total particulate ${ }^{3} \mathrm{H}$ whereas the vast majority was contained in 0.2 to $0.8 \mu \mathrm{m}(70 \%)$ and 0.8 to $3 \mu \mathrm{m}(22 \%)$ cells (Fig. 3b). Microscopic observations showed that the 0.2 to $0.8 \mu \mathrm{m}$ class was primarily free-living bacteria while larger classes included attached bacteria, flagellates, and ciliates (Table 1). Unattached bacteria were also found in $>3 \mu \mathrm{m}$ size fractions, presumably due to dislodgement from detritus.

\section{Clearance rates of ${ }^{14} \mathrm{C}$ - and ${ }^{3} \mathrm{H}$-labeled organisms}

Larval clearance rates, calculated using Eq. (1), show that ${ }^{14} \mathrm{C}$-labeled organisms were cleared at rates
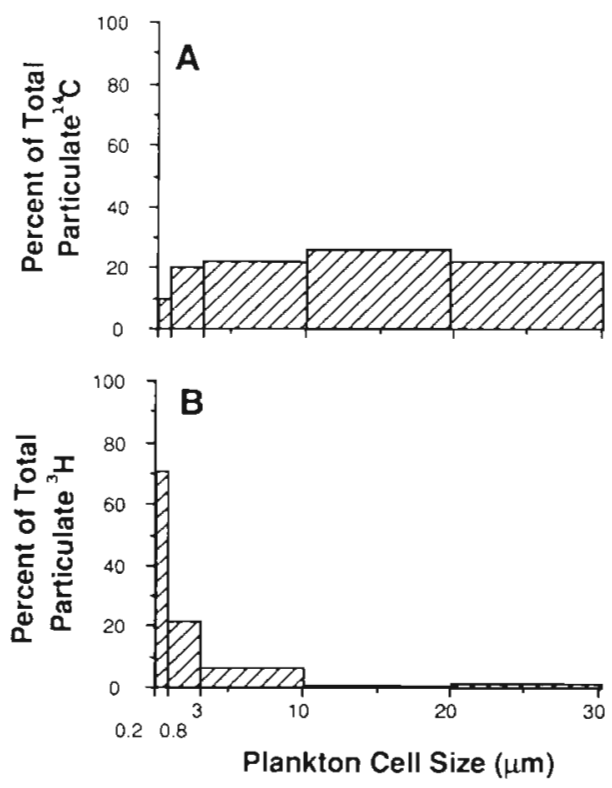

Fig. 3. Percent of total particulate label distributed among plankton size fractions. (A) ${ }^{14} \mathrm{C}$-labeled plankton; (B) ${ }^{3} \mathrm{H}$ labeled plankton

higher than ${ }^{3} \mathrm{H}$-labeled organisms (Figs. 1c \& 2C). As a general trend, larvae cleared particulate ${ }^{3} \mathrm{H}$ and ${ }^{14} \mathrm{C}$ at greater rates when more and larger labeled food items were available. Larvae cleared ${ }^{14} \mathrm{C}$-labeled organisms in the 0.2 to $30 \mu \mathrm{m}$ size class at a significantly greater rate $\left(\mathrm{p}<0.05\right.$ ) than smaller ${ }^{14} \mathrm{C}$-labeled classes (Fig. 1c) Larval clearance rates for the 0.2 to $3 \mu \mathrm{m}, 0.2$ to $10 \mu \mathrm{m}$ and 0.2 to $20 \mu \mathrm{m}$ size classes were similar but all were significantly greater $(p<0.05)$ than clearance of the 0.2 to $0.8 \mu \mathrm{m}$ class. Clearance of ${ }^{3} \mathrm{H}$-labeled organisms in the 0.2 to $30 \mu \mathrm{m}$ size class was significantly greater $(p<0.05)$ than all other size classes. No significant differences in clearance rates were found among any of the size classes $<20 \mu \mathrm{m}$.

\section{Ingestion of protozoans}

In experiments where larvae were fed plankton that had been incubated with ${ }^{3} \mathrm{H}$-thymidine for $15 \mathrm{~min}$ the amounts of particulate ${ }^{3} \mathrm{H}$ ingested were not significantly different between the 0.2 to $3 \mu \mathrm{m}$ and 0.2 to 30 $\mu \mathrm{m}$ size classes (Fig. $4 \mathrm{a}$ ) despite the fact that the 0.2 to $30 \mu \mathrm{m}$ class contained significantly $(p<0.05)$ more particulate ${ }^{3} \mathrm{H}$ (Fig. 4b). Both plankton size classes contained significantly $(\mathrm{p}<0.05)$ more particulate ${ }^{3} \mathrm{H}$ after 120 min than after 15 min of incubation (Fig. 4b) and as a result larvae ingested significantly $(p<0.05)$ more particulate ${ }^{3} \mathrm{H}$ from each size class (Fig. 4a). Larvae ingested significantly $(p<0.05)$ more particulate ${ }^{3} \mathrm{H}$ from the $120 \mathrm{~min}$ labeled 0.2 to $30 \mu \mathrm{m}$ size 

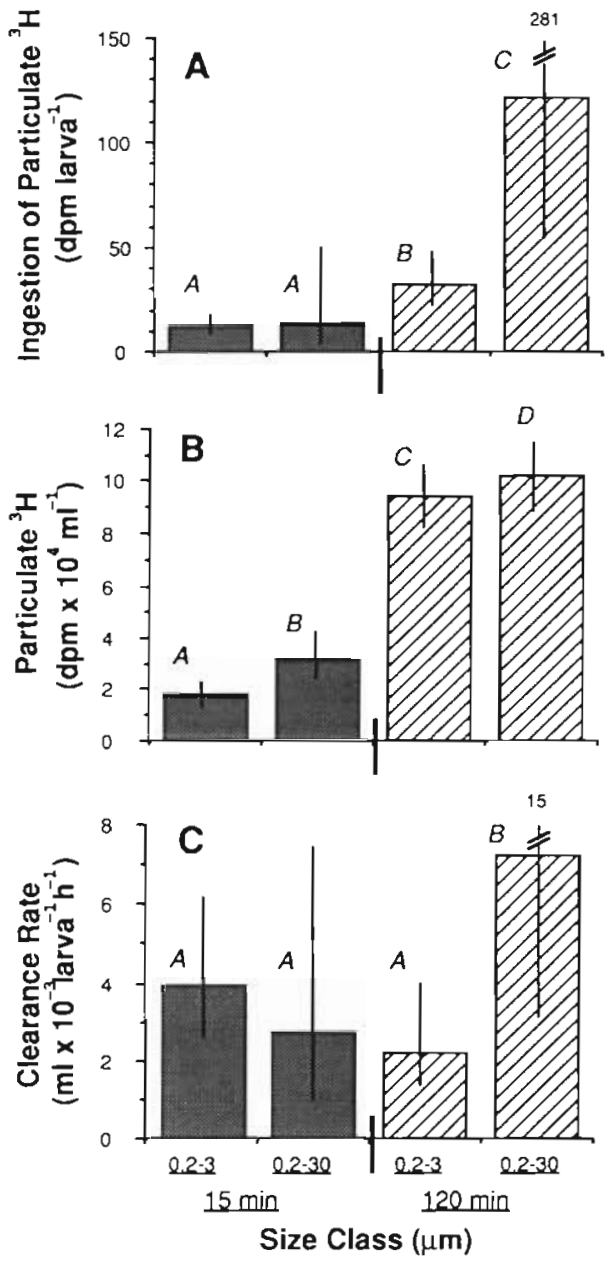

Fig. 4. Crassostrea virginica. Larval ingestion and clearance of ${ }^{3} \mathrm{H}$-labeled plankton size classes at 15 and $120 \mathrm{~min}$. (A) $\mathrm{dpm}$ of ${ }^{3} \mathrm{H}$ ingested per larva; (B) $\mathrm{dpm}$ of ${ }^{3} \mathrm{H}$ per $\mathrm{ml}$ of plankton; (C) clearance rates for plankton size classes. Other details as in Fig. 1

class than from the corresponding 0.2 to $3 \mu \mathrm{m}$ class (Fig. 4a). Larval clearance rates for both size classes prelabeled for 15 min were similar to the clearance of the 0.2 to $3 \mu \mathrm{m}$ class prelabeled for $120 \mathrm{~min}$ but clearance of the 0.2 to $30 \mu \mathrm{m}$ class prelabeled for $120 \mathrm{~min}$ was significantly greater $(p<0.05)$ than all other treatments (Fig. 4c).

In the experiments using cultured heterotrophic flagellates and ciliates, total label uptake by Crassostrea virginica larvae (i.e. uptake of dissolved radiolabeled compounds and labeled cells) was significantly greater $(p<0.05)$ than uptake in control experiments containing dissolved label (flagellate experiment) or dissolved + bacterial label (ciliate experiment), thereby confirming that labeled flagellates and ciliates were ingested. Larvae showed a linear rate of uptake $\left(\mathrm{r}^{2}=0.641, \mathrm{p}=0.0006\right)$ of the labeled flagellate Isonema papillatum over the initial $30 \mathrm{~min}$ of the timecourse feeding experiment (Fig. 5a). Between 30 and 60 min the rate of uptake declined, suggesting that the flux of particulate ${ }^{14} \mathrm{C}$ to and from the larval gut had reached steady state and that assimilation of ${ }^{14} \mathrm{C}$ alone accounted for the subsequent slower rate of increase in dpm larva ${ }^{-1}$ (Fig. 5a). The ingestion rate of 1 . papillatum by oyster larvae was based on the least-squares regression for the linear portion (0 to $30 \mathrm{~min}$ ) of the ${ }^{14} \mathrm{C}$ uptake curve: ${ }^{14} \mathrm{C}$ uptake $\left(\mathrm{dpm}\right.$ larva $\left.{ }^{-1}\right)=0.33492(X)+$ 0.71021 , where $X=$ time (min). Specific activity of prelabeled $I$. papillatum was $0.013 \mathrm{dpm}$ cell ${ }^{-1}$. The clearance rate of $I$. papillatum was $0.0640 \mathrm{ml}$ larva $^{-1} \mathrm{~h}^{-1}$.

Larvae ingested the labeled ciliate Smcil but uptake was exponential $\left(r^{2}=0.843, p=0.0001\right)$ over the 360 min feeding timecourse (Fig. 5b). This pattern of uptake may be the combined result of high larval assimilation of ${ }^{3} \mathrm{H}$-labeled Smcil and an increase in the specific activity of Smcil over the 360 min timecourse. The specific activity of Smcil could increase since both residual dissolved ${ }^{3} \mathrm{H}$-labeled compounds and ${ }^{3} \mathrm{H}$ labeled bacteria were present in whole water samples taken from the washed Smcil culture. Therefore, in the presence of the $<30 \mu \mathrm{m}$ plankton Smcil may have ingested newly labeled natural bacteria as well as prelabeled cultured bacteria. The $<5 \mu \mathrm{m}$ control experi-
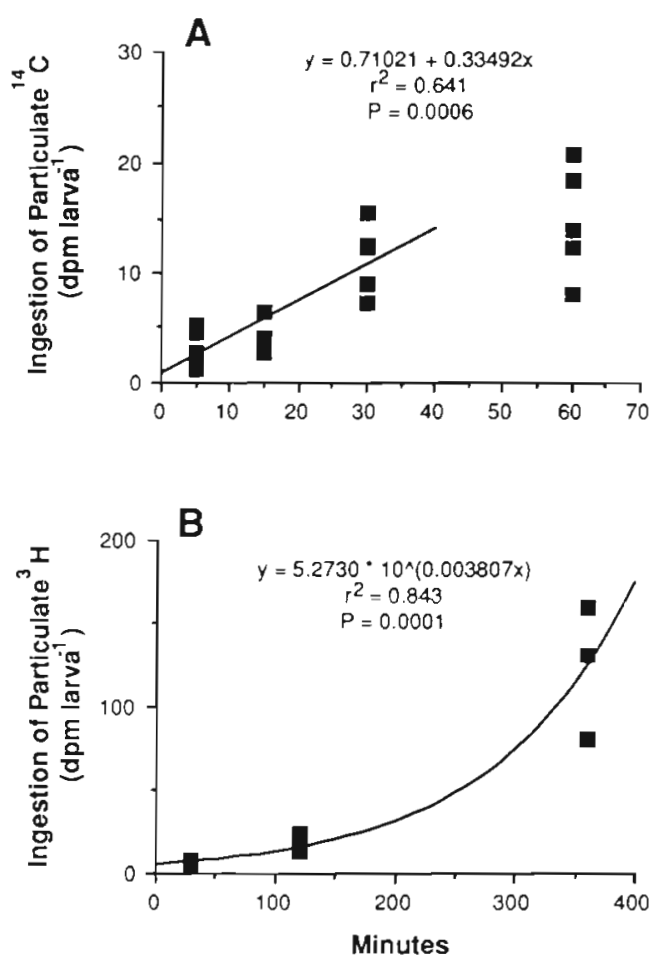

Fig. 5. Crassostrea virginica. Larval ingestion of cultured C-labeled Isonema papillatum (A) and ${ }^{3} \mathrm{H}$-labeled Smcil (B). Each point represents the mean dpm per larva per replicate vial 
ment would not have accounted for such an increase in specific activity of Smcil since Smcil were not present in $<5 \mu \mathrm{m}$ samples taken from the washed Smcil culture. Similar patterns of uptake by grazing zooplankton have been demonstrated in experiments where grazers feed on prey organisms in the presence of radiolabeled substrate (e.g. Roman \& Rublee 1981). The ingestion rate of Smcil by oyster larvae was based on the least-squares regression fitted to the entire $(0$ to $360 \mathrm{~min}){ }^{3} \mathrm{H}$ uptake curve: ${ }^{3} \mathrm{H}$ uptake $\left(\mathrm{dpm}\right.$ larva $\left.{ }^{-1}\right)=$ $10^{0.003807|X|} \times 5.2730$, where $X=$ time $(\mathrm{min})$. Specific activity of prelabeled Smcil was $4.8 \mathrm{dpm} \mathrm{cell}^{-1}$. The clearance rate of Smcil was $0.1093 \mathrm{ml} \mathrm{larva}^{-1} \mathrm{~h}^{-1}$.

\section{DISCUSSION}

\section{Diet composition}

One of our primary goals was to determine whether Crassostrea virginica larvae consume non-phytoplankton foods from the natural environment. Hence, a critical assumption for our study held that particulate ${ }^{3} \mathrm{H}$ uptake by oyster larvae represented the ingestion of ${ }^{3} \mathrm{H}$-labeled heterotrophic bacteria and/or ${ }^{3} \mathrm{H}$-labeled phagotrophic protozoans. Following the 120 min incubation of $<30 \mu \mathrm{m}$ Choptank River plankton with ${ }^{3} \mathrm{H}$-thymidine we found that of the total particulate ${ }^{3} \mathrm{H}$ retained on $0.2 \mu \mathrm{m}$ filters, 70.3 and $92 \%$ passed through $0.8 \mu \mathrm{m}$ and $3 \mu \mathrm{m}$ filters, respectively (Fig. 3b). Over 98.9 and $99.8 \%$ of the heterotrophic bacteria were counted in the 0.2 to $0.8 \mu \mathrm{m}$ and 0.2 to $3 \mu \mathrm{m}$ size classes, respectively (Table 1). Furthermore, heterotrophic bacteria accounted for over 99.9 and $97.6 \%$ of the total cells enumerated in the 0.2 to $0.8 \mu \mathrm{m}$ and 0.2 to $3 \mu \mathrm{m}$ size classes, respectively (Table 1 ). These findings confirm that heterotrophic bacteria were labeled with ${ }^{3} \mathrm{H}$-thymidine and strongly suggest that they dominated particulate matter labeled with ${ }^{3} \mathrm{H}$. Similar correspondence between size fractioned particulate ${ }^{3} \mathrm{H}$ and bacterial abundance has been documented in other studies using ${ }^{3} \mathrm{H}$-thymidine (e.g. Fuhrman \& Azam 1980, Fuhrman et al. 1986). Furthermore, one of these studies (Fuhrman et al. 1986) also used microautoradiography to confirm the nearly exculsive uptake of ${ }^{3} \mathrm{H}$-thymidine and ${ }^{3} \mathrm{H}$-adenine by heterotrophic bacteria. Based on the dominant role of $<3 \mu \mathrm{m}$ heterotrophic bacteria in the uptake of ${ }^{3} \mathrm{H}$ thymidine in our study, and similar findings from previously discussed autoradiograghpy studies (Fuhrman \& Azam 1982, Bern 1985, Fuhrman et al. 1986, Douglas et al. 1987, Carman 1990), we further conclude that 3 to $30 \mu \mathrm{m}{ }^{3} \mathrm{H}$-labeled organisms were attached bacteria and, to a lesser extent (see below), phagotrophic protozoans which had consumed ${ }^{3} \mathrm{H}$-labeled bacteria.
As a result, we feel confident that the ingestion of particulate ${ }^{3} \mathrm{H}$ by $\mathrm{C}$. virginica larvae represents ingestion of heterotrophic bacteria and phagotrophic protozoans.

Results from our feeding experiments using duallabeled natural plankton samples and labeled protozoan cultures indicate that planktotrophic larvae of Crassostrea virginica feed as omnivores, consuming heterotrophic bacteria and phagotrophic protozoans in addition to phototrophs. A previous study by Fritz et al. (1984) demonstrated that $C$. virginica larvae could feed on a variety of phytoplankton taxa found in natural plankton assemblages of Delaware Bay, USA. In the present study, ingestion of ${ }^{14} \mathrm{C}$-labeled organisms by oyster larvae also indicates their ability to ingest naturally occurring phytoplankton and other phototrophic organisms (possibly mixotrophic protozoans). While it is possible that oyster larvae ingested ${ }^{14} \mathrm{C}$-labeled phagotrophic protozoans (which could include mixotrophic and obligate heterotrophic protozoans) it is likely that at least some, and probably most, of the ingested particulate ${ }^{14} \mathrm{C}$ was in the form of phototrophs given the abundance of these organisms in the $<30 \mu \mathrm{m}$ plankton (Table 1).

Laboratory studies have indicated that bivalve larvae can feed upon cultured bacteria (e.g. Hidu \& Tubiash 1963, Martin \& Mengus 1977, Douillet 1991). However, it is generally thought that these larvae are incapable or extremely inefficient at capturing particles as small as most natural free-living bacteria $(<0.5$ $\mu \mathrm{m}$; Ducklow et al. 1988). Our results indicate that prodissoconch II oyster larvae are capable of capturing and ingesting free-living bacteria as small as 0.2 to 0.8 $\mu \mathrm{m}$ but larval clearance rates for these cells are low $\left(0.0016 \mathrm{ml}\right.$ larva $\left.{ }^{-1} \mathrm{~h}^{-1}\right)$ (Fig. 2c). Larval ingestion of larger (i.e. 0.8 to $30 \mu \mathrm{m}$ ) forms of bacteria, such as bacterial aggregates or bacteria attached to detritus, was not detected in this study. For example, on the basis of feeding experiments using 15 min prelabeled and size fractioned plankton, we found that oyster larvae consumed equal amounts of particulate ${ }^{3} \mathrm{H}$ (i.e. bacteria) from both the 0.2 to $3 \mu \mathrm{m}$ and 0.2 to $30 \mu \mathrm{m}$ size classes, despite the fact that the 0.2 to $30 \mu \mathrm{m}$ class contained more particulate ${ }^{3} \mathrm{H}$ than the 0.2 to $3 \mu \mathrm{m}$ class (Fig. $4 \mathrm{a}, \mathrm{b})$. These results indicate that while 3 to $30 \mu \mathrm{m}$ bacteria (predominately attached cells, Table 1) were labeled with ${ }^{3} \mathrm{H}$-thymidine, only 0.2 to $3 \mu \mathrm{m}$ bacteria (predominately free-living cells, Table 1) were ingested. Assuming that larvae do not discriminate between free and attached forms of bacteria, this result may indicate that larvae selected against the particles to which bacteria were attached.

Our results also demonstrate that oyster larvae ingest phagotrophic protozoans. For example, in the above experiments using natural plankton, larvae 
ingested similar amounts of particulate ${ }^{3} \mathrm{H}$ from the 0.2 to $3 \mu \mathrm{m}$ and 0.2 to $30 \mu \mathrm{m}$ size classes incubated for $15 \mathrm{~min}$ but larvae ingested more particulate ${ }^{3} \mathrm{H}$ from the 0.2 to $30 \mu \mathrm{m}$ class than from the 0.2 to $3 \mu \mathrm{m}$ class after a $120 \mathrm{~min}$ prelabeling period (Fig. 4a). This indicates that 3 to $30 \mu \mathrm{m}$ organisms were ingested by larvae but ingestion was detected only after these organisms had been prelabeled for $>15 \mathrm{~min}$. Since 3 to $30 \mu \mathrm{m}$ organisms were labeled at $15 \mathrm{~min}$ (mainly attached bacteria) but not ingested (Fig. $4 \mathrm{a}$, b), the 3 to $30 \mu \mathrm{m}$ organisms ingested after 120 min most likely were phagotrophic protozoans that had consumed particulate ${ }^{3} \mathrm{H}$. The ability of oyster larvae to capture and ingest heterotrophic protozoans was confirmed in grazing experiments using cultured flagellates and ciliates (Fig. 5)

The inclusion of heterotrophs in a mixed particle diet may serve to enhance the growth and development of Crassostrea virginica larvae. Numerous laboratory studies have demonstrated increased larval growth and survival when fed mixed algal diets (for review see Webb \& Chu 1983) and other work has demonstrated enhanced growth of $C$. virginica and other bivalve larvae when fed certain mixed diets of algae and bacteria (Hidu \& Tubiash 1963, Douillet 1991). Due to the small size of most bacteria and the low clearance rates oyster larvae demonstrated for these cells, bacteria may contribute more in terms of essential nutrients (e.g. amino acids or B-complex vitamins; Phillips 1984) than energy. Phagotrophic protozoans may also contribute nutrients and energy to oyster larvae. In a study of other grazing zooplankton Stoecker \& Egloff (1987) demonstrated enhanced egg production in the copepod Acartia tonsa when fed mixed diets including heterotrophic ciliates. Phillips (1984) suggested that protozoans may provide important nutrients such as sterols and polyunsaturated fatty acids. We have found that the cultured ciliate used in our experiments contains n3-polyunsaturated fatty acids (Baldwin \& Newell unpubl.), which are thought to be required for growth and development of certain bivalve larvae (Helm \& Laing 1987, Whyte et al, 1989).

In addition to the types of naturally occurring organisms that prodissoconch II oyster larvae ingest, our results also demonstrate that these larvae can ingest 0.21 to $21.1 \mu \mathrm{m}$ fluorescent microspheres and a wide size range of food particles 10.2 to $0.8 \mu \mathrm{m}$ to 20 to $30 \mu \mathrm{m}$. cells\}. In general, larvae cleared 0.2 to $0.8 \mu \mathrm{m}$ plankton at lower rates than larger classes (Figs. 1c \& 2c). This may reflect a depressed clearance rate under relatively low food biomass concentrations (i.e. a functional response as described by Lam \& Frost 1976, Gallager 1988 ) and, to a certain extent, poor retention of these cells on the velum (see Walne 1965, Riisgård et al. 1980. Sprung 1984, Riisgård 1988). We also found that larvae cleared 0.2 to $3 \mu \mathrm{m}$ cells (i.e. picoplankton size organisms) at similar rates as 0.2 to $20 \mu \mathrm{m}$ cells. While this may be explained in terms of the larval functional response, it may also indicate that picoplankton size cells are cleared as efficiently as larger nanoplankton size cells. Efficient clearance of picoplankton size cells was also reported by Gallager (1988) in a study of particle manipulation by $100 \mu \mathrm{m}$ and $234 \mu \mathrm{m}$ larvae of the bivalve Mercenaria mercenaria. In those experiments, both sizes of larvae cleared the cyanobacterium Synechococcus spp. $(1 \times 0.5 \mu \mathrm{m})$ at rates greater than the alga Isochrysis aff. galbana $(4.5 \mu \mathrm{m}$ diameter) when fed mixtures of these cells (each at $3 \times 10^{4}$ cells $\mathrm{ml}^{-1}$ ). Together, these results suggest that relatively small organisms, such as the picophytoplankton assemblages that are highly abundant in coastal marine systems (e.g Davis et al. 1985, Geider 1988, Ray et al. 1989), may be important food sources for oyster and other bivalve larvae.

Our results also demonstrate that prodissoconch II oyster larvae ingest relatively large cells (20 to $30 \mu \mathrm{m}$, Figs. 1a \& 2a) and fluorescent microspheres $(21.1 \mu \mathrm{m})$. Mackie (1969) also found that Crassostrea virginica larvae could ingest cells in this size range. Although planktonic food organisms of this size generally are numerically less abundant than smaller cells (Table 1 ; Ray et al. 1989), larvae may still acquire significant amounts of energy and nutrition from these organisms given their large cell volume. As an illustration, we can compare estimates of the total cell volume (= biomass) of phototrophs ingested by larvae from the 0.8 to $3 \mu \mathrm{m}$ and 20 to $30 \mu \mathrm{m}$ plankton size fractions. Briefly, in Table 2 we use data on cell abundance and larval ingestion of particulate ${ }^{14} \mathrm{C}$ and ${ }^{3} \mathrm{H}$ to estimate the numbers of cells ingested from different size fractions (see discussion below regarding assumptions used in these calculations). Based on these ingestion rates, and assuming (1.) a mean equivalent spherical diameter of $3 \mu \mathrm{m}$ (a liberal estimate) and cell volume of $10.6 \mu \mathrm{m}^{3}$ cell ${ }^{-1}$ for 0.8 to $3 \mu \mathrm{m}$ cells and (2) a mean equivalent spherical diameter of $21 \mu \mathrm{m}$ (a potentially conservative estimate) and cell volume of $3637 \mu^{3} \mathrm{c}^{3} \mathrm{cell}^{-1}$ for 20 to 30 $\mu \mathrm{m}$ cells, we estimate ingestion rates of $1.21 \times 10^{5} \mu \mathrm{m}^{2}$ cell volume larva ${ }^{-1} \mathrm{~h}^{-1}$ and $9.13 \times 10^{5} \mathrm{\mu m}^{3}$ cell volume larva ${ }^{-1} \mathrm{~h}^{-1}$ for 0.8 to $3 \mu \mathrm{m}$ and 20 to $30 \mu \mathrm{m}$ cells, respectively. Thus, although 0.8 to $3 \mu \mathrm{m}$ cells were 105 times as abundant as 20 to $30 \mu \mathrm{m}$ cells and ingested at 4.5 times the rate for 20 to $30 \mu \mathrm{m}$ cells (in terms of cell number), larvae may have ingested 75 times more biomass from 20 to $30 \mu \mathrm{m}$ cells. Selective ingestion of 20 to $30 \mu \mathrm{m}$ cells (see below) contributed to this high estimate, hence, it is unclear whether $C$. virginica larvae typically ingest large cells in this quantity. Even so, the above analysis suggests that relatively large but scarce cells should not be overlooked when con- 


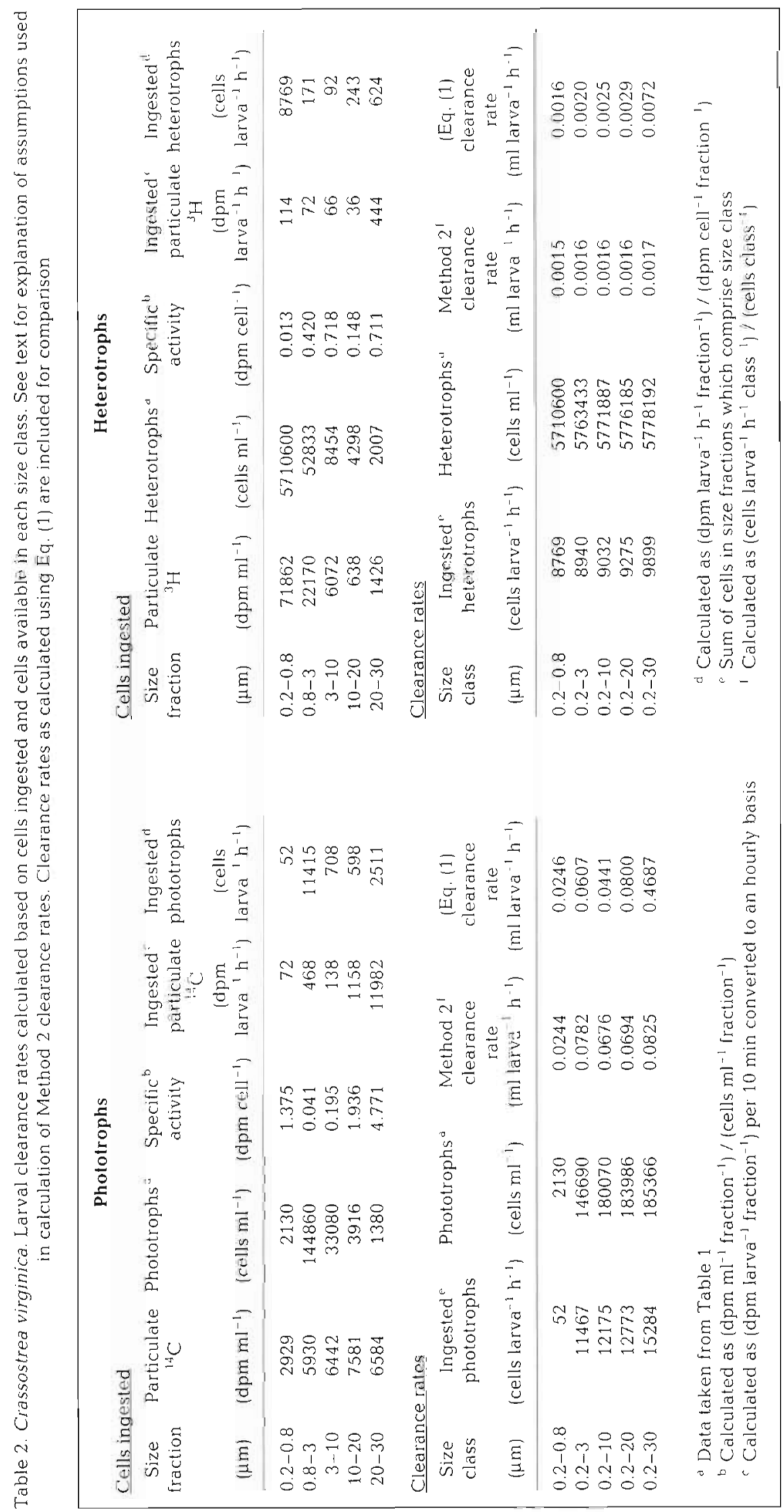


sidering the relative importance of naturally occurring cells in the diets of bivalve larvae.

\section{Food selection}

Not only did we find ingestion of relatively large cells in this study, but it appears that larvae selectively ingested 20 to $30 \mu \mathrm{m}$ cells. As shown in Figs. 1 \& 2 , larval clearance rates for 0.2 to $30 \mu \mathrm{m}$ organisms were much greater than for those in the 0.2 to $20 \mu \mathrm{m}$ size class. These results imply that the ingestion of 20 to 30 $\mu \mathrm{m}$ cells was the reason for the higher clearance of 0.2 to $30 \mu \mathrm{m}$ organisms. Over 87 and $61 \%$ of the total particulate ${ }^{14} \mathrm{C}$ and ${ }^{3} \mathrm{H}$, respectively, ingested by oyster larvae when fed 0.2 to $30 \mu \mathrm{m}$ plankton was in the form of 20 to $30 \mu \mathrm{m}$ cells. Such a result might be expected if (1) larvae did not discriminate among cells in the 0.2 to $30 \mu \mathrm{m}$ class and (2) the 20 to $30 \mu \mathrm{m}$ size fraction contained a disproportionately high amount of the total label present in the 0.2 to $30 \mu \mathrm{m}$ class. However, the amount of particulate ${ }^{14} \mathrm{C}$ in all size fractions was similar and a very low percentage $(1.4 \%)$ of the total particulate ${ }^{3} \mathrm{H}$ was in the 20 to $30 \mu \mathrm{m}$ fraction (Fig. 3) These results suggest that oyster larvae must have selectively ingested 20 to $30 \mu \mathrm{m}$ organisms in order to acquire such a disproportionate amount of particulate label from these cells. Furthermore, even if the 20 to 30 $\mu \mathrm{m}$ fraction did contain a large amount of the total label in the 0.2 to $30 \mu \mathrm{m}$ class, the clearance rates for this size class would not have been dramatically higher than that for the $<20 \mu \mathrm{m}$ classes since, using Eq. (1), we compare the large amount of ingested label to the large amount of label present. In other words, this clearance rate would be similar to rates calculated for the $<20 \mu \mathrm{m}$ size classes where relatively small amounts of ingested label were compared to small amounts of label present. Clearance rates for the 0.2 to $30 \mu \mathrm{m}$ class could only have been higher if the larvae selectively ingested 20 to $30 \mu \mathrm{m}$ cells.

In addition, differences in the amount of particulate label among size fractions would not have led to the high clearance rate for the 0.2 to $30 \mu \mathrm{m}$ size class, and therefore this factor could not be mistaken for selective ingestion by larvae. It is evident that the amount of particulate label as well as the average specific activity of cells is different for each plankton size fraction (Table 2). It is also likely that each size fraction contained a different percentage of cells that were labeled. Both cell-specific activity and percentage of cells labeled (as well as the number of cells present) will contribute to the amount of label found in each size fraction. However, since we compare with Eq. (1) the amount of label ingested in a given size class to the amount of label present, assuming that oyster larvae treat cells within each size fraction in a similar fashion, we would expect to find similar clearance rates among different size classes, regardless of the amount or nature of distribution of label in the various size fractions that constitute the different size classes. Our data support this conclusion. For example, clearance rates of ${ }^{14} \mathrm{C}$-labeled organisms in the 0.2 to $3 \mu \mathrm{m}, 0.2$ to $10 \mu \mathrm{m}$, and 0.2 to $20 \mu \mathrm{m}$ size classes were not significantly different from each other (Fig. 1c) despite the fact that the fractions within these classes were non-uniformly labeled (Table 2). Based on these results, if oyster larvae captured and ingested 20 to $30 \mu \mathrm{m}$ cells in a manner similar to that for $<20 \mu \mathrm{m}$ cells, they would have cleared a similar fraction of the total available particulate ${ }^{14} \mathrm{C}$ or ${ }^{3} \mathrm{H}$, and therefore clearance rates as calculated using Eq. (1) would have been similar to those of smaller size classes. However, since we found a significantly higher clearance rate for the 0.2 to 30 $\mu \mathrm{m}$ class, and because differences in the amount of label within size fractions would not have caused this, the feeding behavior of the larvae must be the underlying cause of the high clearance rate. This strongly suggests that oyster larvae ingested the 20 to $30 \mu \mathrm{m}$ cells in a preferential manner as compared to $<20 \mu \mathrm{m}$ cells.

Based on previous studies which show that retention efficiency in larval bivalves declines for particles greater than ca $4 \mu \mathrm{m}$ (Walne 1965, Riisgård et al. 1980 . Sprung 1984, Riisgard 1988) we conclude that the high clearance of 20 to $30 \mu \mathrm{m}$ cells is not due to enhanced cell retention on the velum per se, but is the result of active selection by larvae. Gallager (1988) found that Mercenaria mercenaria larvae could discriminate among captured food cells both at the mouth and near the junction of the esophagus and stomach. While this remains unconfirmed, it is likely that Crassostrea virginica larvae possess similar discriminatory capabilities.

We are not certain of the type or types of cells that were selectively ingested by oyster larvae in the present study. However, since larvae selectively ingested both ${ }^{14} \mathrm{C}$-and ${ }^{3} \mathrm{H}$-labeled 20 to $30 \mu \mathrm{m}$ cells it is possible that larvae ingested organisms that were dual-labeled, cells that were labeled with ${ }^{14} \mathrm{C}$ or ${ }^{3} \mathrm{H}$, or a combination of all. three. As discussed previously, it does not appear that larvae ingested attached bacteria. Thus, if 20 to 30 $\mu \mathrm{m}$ heterotrophs other than attached bacteria accounted for the ingested particulate ${ }^{3} \mathrm{H}$, and all 20 to 30 $\mu \mathrm{m}$ bacteria were labeled at the same specific activity as 0.2 to 0.8 bacteria $\left(0.013 \mathrm{dpm}_{\text {cell }}{ }^{-1}\right.$. Table 2), this would require that the ingested heterotrophic protozoans from the 20 to $30 \mu \mathrm{m}$ size fraction have a specific activity of $58 \mathrm{dpm}_{\text {cell }}^{-1}$ Clearly this is unrealistic given that our ${ }^{3} \mathrm{H}$-labeled Smcil culture achieved only $4.8 \mathrm{dpm} \mathrm{cell}^{-1}$ after $12 \mathrm{~h}$ of incubation. For this reason we feel that much of the ingested 20 to $30 \mu \mathrm{m}$ parti- 
culate label was derived from dual-labeled mixotrophs (i.e. organisms categorized as 'phototrophs' in Table 1 given their possession of autofluorescent pigments). While some of these mixotrophs were probably categorized as 'other' phototrophs (Table 1), we believe the dominant mixotrophs in the 20 to $30 \mu \mathrm{m}$ size fraction were the blooming dinoflagellates Gyrodinium uncatenum and Gymnodinium sanguinium. Both these species have been found to consume particulate foods (Bockstahler \& Coats 1990); hence, these large mixotrophic cells could have incorporated high amounts of ${ }^{14} \mathrm{C}$-bicarbonate (Table 2) and they could have phagocytized heterotrophic organisms that were labeled with ${ }^{3} \mathrm{H}$. If these organisms are included in estimates of the specific activity of ingested ${ }^{3} \mathrm{H}$-labeled cells from the 20 to $30 \mu \mathrm{m}$ size fraction, we obtain more realistic values of $1.66 \mathrm{dpm}_{\text {cell }}{ }^{-1}$

Our finding of selective ingestion for 20 to $30 \mu \mathrm{m}$ cells by Crassostrea virginica larvae appears to conflict with the results of Fritz et al. (1984) who found that $C$. virginica larvae selectively ingested $<10 \mu \mathrm{m}$ versus $>10 \mu \mathrm{m}$ phytoplankton collected from Delaware Bay. Very likely, this discrepancy can be attributed to the use of different-sized larvae and/or different experimental techniques. For instance, we used larvae with a mean shell length of $179 \mu \mathrm{m}$ whereas Fritz et al. (1984) used 3 sets of larvae, the largest with a mean shell length of $136 \mu \mathrm{m}$. We have found that larvae of shell length ca $150 \mu \mathrm{m}$ can ingest fluorescent microspheres up to $15.8 \mu \mathrm{m}$ diameter whereas larvae of shell length ca $180 \mu \mathrm{m}$ can ingest micropheres up to $21.1 \mu \mathrm{m}$. Given these differences in particle ingestion and the fact that many of the 20 to $30 \mu \mathrm{m}$ cells in our study were oval or cylindrical in shape with minumum linear dimensions of $<20 \mu \mathrm{m}$, it is conceivable that the larger larvae used in our study were capable of ingesting larger plankton cells than the larvae used by Fritz et al. (1984). Another contributing factor may simply be the difference in the plankton assemblages used in each study. Also, Fritz et al. (1984) based their results on the disappearance of phytoplankton (determined microscopically) whereas our results are based on the direct ingestion of labeled cells, which include heterotrophic as well as phototrophic organisms.

\section{Larval clearance rates}

Baars \& Oosterhuis (1985) point out that clearance rates as determined using radioisotope labeling techniques based on the model of Daro (1978) may overestimate actual clearance rates if the grazing organism feeds selectively on a labeled food cell of high specific activity. Since we found such selective feeding by Crassostrea virginica larvae in the present study, we calculated clearance rates for the various plankton size classes using a second technique (Table 2) in order to check for erroneously high clearance rates derived using Eq. (1). Here, we use data on cell abundance (Table 1) and larval ingestion of particulate ${ }^{14} \mathrm{C}$ and ${ }^{3} \mathrm{H}$ (Figs. 1a \& 2a) to estimate the numbers of cells ingested from different size fractions. Using these estimates we can then calculate larval clearance rates for phototrophs and heterotrophs present in each size class (made up of one or more size fractions). This approach provides clearance rate estimates based on cell number as opposed to rates based on the level of radiolabel in the larvae and plankton size class, as calculated using Eq. (1). We will hereafter refer to Table 2 estimates as 'Method 2' clearance rates.

For ease of calculation in Table 2 we have assumed that: (1) all ingested particulate ${ }^{14} \mathrm{C}$ was derived from phototrophs and all ingested particulate ${ }^{3} \mathrm{H}$ was derived from heterotrophs, (2) all enumerated phototrophs and heterotrophs were labeled, and (3) all cells within a given size fraction were uniformly labeled (i.e. of equal specific activity). Because it is possible that these conditions were not strictly met, actual values of ingested cell number and clearance rates may differ somewhat from our estimates. However, rates calculated using Method 2 are in general agreement with those determined using Eq. (1) (Table 2) and both sets of data are in general agreement with clearance rates reported for other bivalve larvae (Table 3). Two exceptions are the ${ }^{14} \mathrm{C}$ - and ${ }^{3} \mathrm{H}$-based rates for the 0.2 to $30 \mu \mathrm{m}$ size class as calculated using Eq. (1). Clearly, our ${ }^{14} \mathrm{C}$-based rate is much higher (nearly 6 -fold) than the corresponding Method 2 rate (Table 2), and it is also much higher than rates reported for other bivalve larvae (Table 3 ). Although our ${ }^{3} \mathrm{H}$-based rate using Eq. (1) is not unusually high compared with literature values (Table 3 ) it is over 4 times higher than the Method 2 rate (Table 2). We therefore conclude that the Eq. (1)-based clearance rates for 0.2 to $30 \mu \mathrm{m}$ organisms overestimate the actual clearance rate of these organisms and, in agreement with Baars \& Oosterhuis (1985), we assume these rates are the direct result of larval selection for high specific activity cells present in the 20 to $30 \mu \mathrm{m}$ size fraction. For the 0.2 to $30 \mu \mathrm{m}$ size class then, we feel that Method 2 clearance rates are more realistic and conservative. We do not think Eq. (1)-based rates for the other size classes are in question since they agree with Method 2 rates (Table 2) and other clearance rates found in the literature (Table 3).

Further examination of clearance rates generated in this study indicates that ${ }^{14} \mathrm{C}$-labeled cells were cleared at higher rates than ${ }^{3} \mathrm{H}$-labeled cells (Table 2 ). While this may suggest that oyster larvae feed primarily on ${ }^{14} \mathrm{C}$-labeled organisms (see Roman \& Rublee 1981, 
Table 3. Clearance rates of bivalve larvae reported in the literature

\begin{tabular}{|c|c|c|c|c|c|c|}
\hline Species & $\begin{array}{l}\text { Shell length } \\
\qquad(\mu \mathrm{m})\end{array}$ & $\begin{array}{l}\text { Temp. } \\
\left({ }^{\circ} \mathrm{C}\right)\end{array}$ & Food & $\begin{array}{c}\text { Clearance } \\
\text { rate } \\
\left(m l \text { larva } h^{-1}\right)\end{array}$ & Method & Source \\
\hline \multirow{4}{*}{$\begin{array}{l}\text { Crassostrea } \\
\text { virginica }\end{array}$} & 179 & 25 & $<30 \mu \mathrm{m}$ natural plankton & $0.0017-0.0825$ & Radioisotope labeling & This study \\
\hline & 237 & 22 & Isonema papillatum & 0.0640 & Radioisotope labeling & This study \\
\hline & 273 & 22 & Cultured ciliate Smcil & 0.1093 & Radioisotope labeling & This study \\
\hline & $300-376$ & 22 & Isochrysis galbana & 0.0541 & Coulter Counter & Widdows et al. (1989) \\
\hline $\begin{array}{l}\text { Crassostrea } \\
\text { gigas }\end{array}$ & $89-294$ & 25 & $\begin{array}{l}\text { Isochrysis galbana }+ \\
\text { Chaetoceros calcitrans }\end{array}$ & $0.0023-0.0935$ & Coulter Counter & Gerdes (1983) \\
\hline $\begin{array}{l}\text { Crassostrea } \\
\text { gigas }\end{array}$ & 213 & 21 & $\begin{array}{l}\text { Tetraselmis suecica + } \\
\text { Nannochloris } \mathrm{sp} \text {. }\end{array}$ & $0.0017-0.0105$ & Hemacytometer & Crisp et al. (1985) \\
\hline $\begin{array}{l}\text { Ostrea } \\
\text { edulis }\end{array}$ & 230 & 21 & $\begin{array}{l}\text { Tetraselmis suecica }+ \\
\text { Isochrysis galbana }\end{array}$ & $0.0025-0.0097$ & Hemacytometer & Crisp et al. (1985) \\
\hline \multirow{2}{*}{$\begin{array}{l}\text { Mercenaria } \\
\text { mercenaria }\end{array}$} & $100-234$ & 22 & Isochrysis galbana & $0.0000093-0.0994$ & Video micoscopy & Gallager (1988) \\
\hline & $93-164$ & 28 & Isochrysis galbana & $0.0115-0.0552$ & Coulter Counter & Riisgård (1988) \\
\hline \multirow{3}{*}{$\begin{array}{l}\text { Mytilus } \\
\text { edulis }\end{array}$} & $120-250$ & 18 & Isochrysis galbana & $0.017-0.052$ & Coulter Counter & Sprung (1984) \\
\hline & $125-250$ & $17-19$ & $\begin{array}{l}\text { Isochrysis galbana }+ \\
\text { Monochrysis lutheri }\end{array}$ & $0.0118-0.0853$ & Coulter Counter & $\begin{array}{l}\text { Jespersen \& } \\
\text { Olsen }(1982)\end{array}$ \\
\hline & $110-220$ & 15 & $\begin{array}{l}\text { Isochrysis galbana }+ \\
\text { Monochrysis lutheri }\end{array}$ & $0.0125-0.0967$ & Coulter Counter & $\begin{array}{l}\text { Riisgård \& } \\
\text { Randlov (1981) }\end{array}$ \\
\hline
\end{tabular}

Lessard \& Swift 1985), the disparity in rates is at least in part because ${ }^{3} \mathrm{H}$-based clearance rates calculated for all size classes were kept low due to the presence of abundant and poorly retained 0.2 to $0.8 \mu \mathrm{m}$ heterotrophic bacteria. In other words, in both ${ }^{3} \mathrm{H}$-based clearance rate determinations (Eq. (1) and Method 2) the denominator of the equation was dominated by abundant 0.2 to $0.8 \mu \mathrm{m}$ bacteria; in terms of particulate ${ }^{3} \mathrm{H}$, these cells contained $70 \%$ of the total label available (Fig 3b) and in terms of cell numbers these cells represented $99 \%$ of the total (Table 2). Because these small cells were cleared so poorly (Fig. 2c) and the larger ${ }^{3} \mathrm{H}$-labeled cells were relatively few in number (Table 1) and contained so little ${ }^{3} \mathrm{H}$ (Fig. 3b), the ingested number of large cells or forms of particulate ${ }^{3} \mathrm{H}$ was small relative to the total number of cells or particulate ${ }^{3} \mathrm{H}$ available in each size class. As a result, clearance rates were low. In contrast, because particulate ${ }^{14} \mathrm{C}$ was more evenly distributed among size fractions (Fig. 3a) and small, less efficiently retained ${ }^{14} \mathrm{C}$-labeled cells did not dominate total cell number to the degree seen for ${ }^{3} \mathrm{H}$-labeled cells, ${ }^{14} \mathrm{C}$-based clearance rates were higher and were likely more realistic. It is interesting to note that if we assume oyster larvae are incapable of clearing ${ }^{3} \mathrm{H}$-labeled 0.2 to $0.8 \mu \mathrm{m}$ cells, i.e. we calculate clearance rates for 0.8 to $30 \mu \mathrm{m}$ cells, we derive rates as high as ca $0.0245 \mathrm{ml}$ larva ${ }^{-1} \mathrm{~h}^{-1}$ (Eq. 1) and $0.0167 \mathrm{ml} \mathrm{larva}^{-1} \mathrm{~h}^{-1}$ (Method 2).
Such rates are similar to those calculated for ${ }^{14} \mathrm{C}$ labeled cells (Table 2) and are ca 10 times higher than those calculated including ${ }^{3} \mathrm{H}$-labeled 0.2 to $0.8 \mu \mathrm{m}$ cells.

\section{CONCLUSION}

In the present study we have determined the sizes and general trophic groups of planktonic organisms that comprise the natural particle diet of Crassostrea virginica larvae. Knowledge of the natural diets of such planktotrophic larvae is central to an understanding of the relationships between in situ food supply and composition and larval growth, survival, and metamorphosis success. It is clear from our resuts that $C$. virginica larvae do not feed exclusively as herbivores in the natural environment. Even in phytoplankton-rich estuaries such as Chesapeake Bay, it appears that oyster larvae consume heterotrophic bacteria and protozoans. Copepods are also known to consume heterotrophic prey in estuaries where standing stocks of phytoplankton are high (Gifford \& Dagg 1988, White 1991). Thus, it is clear that the relationships between larval nutrition and larval growth and survival in the natural environment may not always be explained solely on the basis of phytoplankton abundance or composition. The relative importance of phototrophs and heterotrophs in the diet of oyster larvae is unclear 
but it is possible that heterotrophs play an important supplementary role in larval nutrition. This may be particularly true for phagotrophic protozoans (which have been largely overlooked as a food source for planktotrophic larvae) given their cell size and abundance. The nutritional importance of protozoans has also been suggested for other taxonomic groups of grazing zooplankton (for review see Stoecker \& Capuzzo 1990).

Our experiments also suggest that a wide size range of naturally occurring food organisms may be nutritionally important to Crassostrea virginica larvae. In particular, highly abundant picoplankton assemblages and less abundant but large planktonic organisms may be more important than previously thought. It also appears that oyster larvae can selectively ingest certain naturally occurring plankton cells. Together, omnivory, selective ingestion, and the utilization of a wide size range of food organisms by $C$. virginica larvae suggest that these larvae are well adapted to the complex food environments typical of coastal marine systems.

Acknowledgements. We thank T Diamond and G. Williams for technical assistance and Drs R. Rivkin, E. Lessard, M. Roman, and V. Kennedy for helpful discussions and for improvements in an earlier draft of this manuscript. We also thank D. Meritt for supplying oyster larvae. Dr E. Lessard provided the cultured ciliate Smcil used in this study and Drs D. Coats and G. Small identified the ciliate. Sharyn Hedrick identified the blooming dinoflagellates. The flagellate Isonema papillatum was purchased from the American Type Culture Collection. This study was supported by Grant \#NA86AA-D-SG006 from the National Sea Grant Program, NOAA, to Roger l. E. Newell and Thomas J. Jones (University of Maryland), and a Research Assistantship for B.S.B. provided by Horn Point Environmental Laboratory.

\section{LITERATURE CITED}

Baars, M. A., Oosterhuis, S. S. (1984). Diurnal feeding rhythms in north sea copepods measured by gut fluorescence, digestive enzyme activity and grazing on labeled food. Neth. J. Sea Res. 18: 97-119

Baars, M. A., Oosterhuis, S. S. (1985). Zooplankton grazing in natural water with high concentration of ${ }^{14} \mathrm{C}$ bicarbonate: variable live controls and gut passage time. Hydrobiol. Bull. 19: 71-80

Bayne, B. 1. (1983). The physiological ecology of marine molluscan larvae. In: Verdonk, N. H., van den Biggelaar, J. A. M., Tompa, A. (eds.) The Mollusca, Vol. III, Development. Academic Press, New York, p. 229-343

Berk, S. G., Brownlee, D. C., Heinle, D. R., Kling, H. J., Colwell, R. R. (1977). Ciliates as a food source for marine planktonic copepods. Microb. Ecol. 4: 27-40

Bern, L. (1985). Autoradiographic studies of [methyl $\left.{ }^{3} \mathrm{H}\right]$ thymjdine incorporation in a cyanobacterium (Microcystis wesenbergii)-bacterium associatioin and in selected algae and bacteria. Appl environ. Microbiol. 49: 232-233
Bockstahler, K. R., Coats, D. W. (1990). Mixotrophy in Chesapeake Bay dinoflagellates. J. Protozool. 38: 11 A (Suppl.) (Abstract)

Carman, K. R. (1990). Radioactive labeling of a natural assemblage of marine sedimentary bacteria and microalgae for trophic studies: an autoradiographic study. Microb. Ecol. 19: 279-290

Conley, W. J., Turner, J T (1985). Omnivory by the coastal marine copepods Centropages hamatus and Labidocera aestiva. Mar. Ecol. Prog. Ser. 21. 113-120

Crisp, D. J., Yule, A. B., White, K. N. (1985). Feeding by oyster larvae: the functional response, energy budget and a comparison with mussel larvae. J. mar biol. Ass. U.K. 65: $759-783$

Cuhel, R. L., Waterbury, J. B. (1984). Biochemical composition and short term nutrient incorporation patterns in a unicellular marine cyanobacterium, Synechococcus (WH7803). Limnol. Oceanogr. 29: 370-374

Daro, M. H. (1978). A simplified ${ }^{14} \mathrm{C}$ method for grazing measurements on natural planktonic populations. Helgoländer Meeresunters. 31: 241-248

Davis, P. G., Caron, D. A., Johnson, P. W., Sieburth, J. McN. (1985). Phototrophic and apochlorotic components of picoplankton and nanoplankton in the North Atlantic: geographic, vertical, seasonal and diel distributions. Mar Ecol. Prog. Ser. 21. 15-26

Dolan, J. R., Coats, D. W. (1990). Seasonal abundances of planktonic ciliates and microflagellates in mesohaline Chesapeake Bay waters. Estuar. coast. Shelf Sci. 31. $157-175$

Douglas, D. J., Novitsky, J. A., Fournier, R. O. (1987). Microradiography-based enumeration of bacteria with estimates of thymidine-specific growth and production rates. Mar. Ecol. Prog. Ser. 36: 91-99

Douillet, P. A. (1991). Beneficial effects of bacteria on the culture of larvae of the Pacific oyster Crassostrea gigas (Thunberg). Doctoral dissertation, Oregon State University, Corvallis

Ducklow, H. W., Kirchman, D. L. (1983). Bacterial dynamics and distribution during a spring diatom bloom in the Hudson River plume, USA. J. Plankton Res. 5: $333-354$

Ducklow, H. W., Peele, E. R., Hill, S. M., Quinby, H. L. (1988). Fluxes of carbon, nitrogen, and oxygen through estuarine bacterioplankton. In: Lynch, M. (eds.) Understanding the estuary: advances in Chesapeake Bay Research. Chesapeake Research Consortium Publication 129. Baltimore, Maryland, p. 511-523

Fritz, L. W., Lutz, R. A., Foote, M. A., Van Dover, C. L., Ewart, J. W. (1984). Selective feeding and grazing rates of oyster (Crassostrea virginica) larvae on natural phytoplankton assemblages. Estuaries 7: 513-518

Fuhrman, J. A., Azam, F. (1980). Bacterioplankton secondary production estimates for coastal waters of British Columbia, Antarctica, and California. Appl, environ. Microbiol. 39: 1085-1095

Fuhrman, J. A., Azam, F. (1982). Thymidine incorporation as a measure of heterotrophic bacterioplankton production in marine surface waters: evaluation and field results. Mar. Biol. 66: 109-120

Fuhrman, J. A., Ducklow, H. W., Kirchman, D. L., Hudak, J., McManus, G. B., Kramer, J. (1986). Does adenine incorporation into nucleic acids measure total microbial production? Limnol. Oceanogr. 31: 627-636

Gallager, S. M. (1988). Visual observations of particle manipulation during feeding in larvae of a bivalve mollusc. Bull. mar. Sci. 43: 344-365 
Geider, R. J. (1988). Abundance of autotrophic and heterotrophic nanoplankton and the size distribution of microbial biomass in the southwestern North Sea in October 1986. J. exp. mar. Biol. Ecol. 123: 127-145

Gerdes, D. (1983). The Pacific oyster Crassostrea gigas. Part I. Feeding behaviour of larvae and adults. Aquaculture 31: 195-219

Gifford D. J., Dagg, M. J. (1988). Feeding of the estuarine copepod Acartia tonsa Dana: carnivory vs. herbivory in natural microplankton assemblages. Bull. mar. Sci, 43 : $458-468$

Haas, L. W. (1982). Improved epifluorescent microscopy for observing planktonic micro-organisms. Annls. Inst. océanogr., Paris 58: 261-266

Helm, M. M., Laing, I. (1987). Preliminary observations on the nutritional value of 'Tahiti Isochrysis' to bivalve larvae. Aquaculture 62: 281-288

Hidu H., Tubiash H. S. (1963). A bacterial basis for the growth of antibiotic-treated bivalve larvae. Proc. natn. Shellfish. Ass. 54: 25-29

Hobbie, J. E., Daley, R., Jasper, S. (1977). Use of Nuclepore filters for counting bacteria by fluorescence microscopy. Appl environ. Microbiol. 33: 1225-1228

Jespersen, H., Olsen, K. (1982). Bioenergetics in veliger larvae of Mytilus edulis L. Ophelia 21: 101-113

Kleppel, G. S., Frazel, D., Pieper, R. E., Holliday, D. V. (1988). Natural diets of zooplankton off southern California. Mar. Ecol. Prog Ser. 49: 231-241

Lam, R. K., Frost, B. W. (1976). Model of copepod filtering response to changes in size and concentration of food. Limnol. Oceanogr. 21: 490-500

Landry, M. R. (1981). Switching between herbivory and carnivory by the planktonic marine copepod Calanus pacificus. Mar. Biol. 65: 77-82

Lessard, E. J., Swift, E. (1985). Species-specific grazing rates of heterotrophic dinoflagellates in oceanic waters, measured with a dual-label radioisotope technique. Mar Biol 87: $289-296$

Mackie, G. (1969). Quantitative studies of feeding in the oyster, Crassostrea virginica. Proc. natn. Shellfish. Ass. 59 6-7 (Abstract)

Malone, T. C., Ducklow, H. W. (1990). Microbial biomass in the coastal plume of Chesapeake Bay: phytoplanktonbacterioplankton relationships. Limnol. Oceanogr 35 $296-312$

Malone, T C., Kemp, W. M., Ducklow, H. W., Boyton, W. R., Tuttle, J. H., Jonas, R. B. (1986). Lateral variation in the production and fate of phytoplankton in a partially stratified estuary. Mar. Ecol. Prog Ser. 32 $149-160$

Martin, Y P., Mengus, B. M. (1977). Use of selected bacterial strains for feeding larvae of Mytilus galoprovincialis Link in experimental rearing. Aquaculture 10: 253-262.

Martinez, J., Riera, M., Lalucat, J., Vives-Rego, J. (1989) Thymidine incorporation into algal DNA from axenic cultures of Synechococcus, Chlorella, and Tetraselmis. Lett. appl. Microbiol. 8: 135-138

McManus, G. B., Fuhrman, J. A. (1988). Clearance of bacteria-sized particles by natural populations of nanoplankton in the Chesapeake Bay outflow plume. Mar. Ecol. Prog. Ser. 42: 199-206

McManus, G. B., Fuhrman, J. A. (1990). Mesoscale and seasonal variability of heterotrophic nanoflagellate abundance in an estuarine outflow plume. Mar. Ecol. Prog. Ser 61: $207-213$

Olson, R. R. (1987). In situ culturing as a test of the larval starvation hypothesis in the crown-of-thorns starfish,
Acanthaster planci. Limnol. Oceanogr. 32: 895-904

Olson, R. R., Bosch, I., Pearse, J. S. (1987). The hypothesis of antarctic larval starvation examined for the asteroid Odontaster validus. Limnol. Oceanogr. 32: 686-690

Pechenik, J. A. (1979). Leakage of ingested carbon by gastropod larvae, and its effect on the calculation of assimilation efficiency. Estuaries 2: 45-49

Pechenik, J. A. (1987). Environmental influences on larval survival and development. In: Giese, A. C., Pearse, J. S., Pearse, V. B. (eds.) Reproduction of marine invertebrates, Vol. IX, General aspects: seeking unity in diversity. Blackwell Scientific Publications, Palo Alto, California, p. $551-608$

Phillips, N. W. (1984). Role of different microbes and substrates as potential suppliers of specific, essential nutrients to marine detritivores. Bull. mar. Sci. 35: 283-298

Plaut, W., Sagan, A. (1958). Incorporation of thymidine in the cytoplasm of Amoeba proteus. J. biophys. biochem. Cytol. $4: 843-847$

Pollard, P. C., Moriarty, D. J. M. (1984). Validity of the tritiated thymidine method for estimating bacterial growth rates: measurement of isotope dilution during DNA synthesis. Appl. environ. Microbiol. 48: 1076-1083

Qian, P.-Y., Chia, F.-S. (1990). Detritus as a potential food source for polychaete larvae. J. exp. mar. Biol Ecol. 143: $63-71$

Ray, R. T., Haas, L. W., Sieracki, M. E. (1989). Autotrophic picoplankton dynamics in a Chesapeake Bay sub-estuary. Mar. Ecol. Prog. Ser. 52: 273-285

Riisgård, H. U. (1988). Feeding rates in hard clam (Mercenaria mercenaria) veliger larvae as a function of algal (Isochrysis galbana) concentration. J. Shell. Res. 7: 377-380

Riisgård, H. U., Randløv, A., (1981). Oxygen consumption and clearance as a function of size in Mytilus edulis L. veliger larvae. Ophelia 20:179-183

Riisgård, H. U., Randløv, A., Kristensen, P. S. (1980). Rates of water processing, oxygen consumption and efficiency of particle retention in veligers and young post-metamorphic Mytilus edulis. Ophelia 19: $37-47$

Rivkin, R. B. (1986). Incorporation of tritiated thymidine by eucaryotic microalgae. J. Phycol. 22: 193-198

Rivkin, R. B., Bosch, I., Pearse, J. S., Lessard, E. J. (1986). Bacterivory: a novel feeding mode for asteroid larvae. Science 223: 1311-1314

Rivkin, R. B., Voytek, M. A. (1986). Cell division rates of eucaryotic algae measured by tritiated thymidine incorporation into DNA: coincident measurements of photosynthesis and cell division of individual species of phytoplankton isolated from natural populations. J. Phycol. 22: 199-205

Roman, M. R. (1984a). Utilization of detritus by the copepod Acartia tonsa. Limnol. Oceanogr. 29: 949-959

Roman, M. R. (1984b). Ingestion of detritus and microheterotrophs by pelagic marine zooplankton. Bull. mar. Scl. 35: $477-494$

Roman, M. R., Rublee, P. A. (1981). A method to determine in situ zooplankton grazing rates on natural particle assemblages. Mar. Biol. 65: 303-309

Sagan, L. (1965). An unusual pattern of tritiated thymidine incorporation in Euglena. J. Protozool 12: 105-109

Scherbaum, O. H., Louderback, A. L. (1960). Incorporatıon of tritiated thymidine into heat-treated Tetrahymena. J Protozool. 7 (Suppl.1: 25

Sherr, B. F., Sherr, E. B., Rassoulzadegan, F. (1988). Rates of digestion of bacteria by marine phagotrophic protozoa Temperature dependence. Appl. environ. Microbiol. 54 1091-1095 
Sherr, E. B., Rassoulzadegan, F., Sherr, B. F. (1989). Bacterivory by pelagic choreotrichous ciliates in coastal waters of the NW Mediterranean Sea. Mar Ecol. Prog. Ser 55: $235-240$

Sokal, R. R., Rohlf, J. F. (1981). Biometry, 2nd edn. W. H. Freeman and Co., New York

Sprung, M. (1984). Physiological energetics of mussel larvae (Mytilus edulis). II. Food uptake. Mar. Ecol. Prog. Ser. 17. 295-305

Stoecker, D. K., Capuzzo, J. M. (1990). Predation on Protozoa: its importance to zooplankton. J. Plankton Res. 12: $891-908$

Stoecker, D. K., Egloff, D. A. (1987). Predation by Acartia tonsa Dana on planktonic ciliates and rotifers. J. exp. mar. Biol. Ecol. 110: 53-68

Stoecker, D. K., Sanders, N. K. (1985). Differential grazing by Acartia tonsa on a dinoflagellate and a tintinnid. J. Plankton Res. 7: 85-100

Stoecker, D. K., Taniguchi, A., Michaels, A. E. (1989). Abundance of autotrophic, mixotrophic and heterotrophic planktonic ciliates in shelf and slope waters. Mar. Ecol. Prog. Ser. 50: 241-254

Strathmann, R. R. (1987). Larval feeding. In: Giese, A. C., Pearse, J. S., Pearse, V. B. (eds.) Reproduction of marine invertebrates, Vol. IX, General aspects: seeking unity in diversity. Blackwell Scientific Publications, Palo Alto,

This article was submitted to the editor
California, p. 465-550

Swinton, D. C., Hanawalt, P. C. (1972). In vivo specific labeling of Chlamydomonas chloroplast DNA. J. Cell Biol. 54: $592-597$

Walne, P. R. (1965). Observations on the influence of food supply and temperature on the feeding and growth of the larvae of Ostrea edulis. Fishery Invest, Lond. II 24: 1-45

Webb, K. L., Chu, F.-L. E. (1983). Phytoplankton as a food source for bivalve larvae. In: Pruder, G. D., Langdon, C. Conklin, D. (eds.) Proceedings of the Second International Conference on Aquaculture and Nutrition: Biochemical and Physiological Approaches to Shellfish Nutrition. Louisiana State University, Division of Continuing Education, Baton Rouge, Louisiana, p. 272-291

Widdows, J., Newell, R. I. E., Mann, R. (1989). Effects of hypoxia and anoxia on survival, energy metabolism, and feeding of oyster larvae (Crassostrea virginica, Gmelin). Biol. Bull. mar. biol. Lab., Woods Hole 177: 154-166

White, J. R. (1991). Seasonal study of zooplankton dynamics in the mesohaline Chesapeake Bay. Doctoral dissertation, University of Maryland, College Park

Whyte, J. N. C., Bourne, N., Hodgson, C. A. (1989). Influence of algal diets on biochemical composition and energy reserves in Patinopecten yessoensis (Jay) larvae. Aquaculture 78: $333-347$

Manuscript first received: August 29, 1990

Revised version accepted: October 11, 1991 